\title{
CODETERMINATION: A POOR FIT FOR U.S. CORPORATIONS
}

\author{
Jens Dammann* and Horst Eidenmüller**
}

The idea that a corporation's employees should elect some of the corporation's board members, a system known as codetermination, has moved to the forefront of U.S. corporate law policy. Elizabeth Warren's Accountable Capitalism Act calls for employees of large firms to elect forty percent of all board members. Bernie Sanders's Corporate Accountability and Democracy Plan goes even further and states that workers should elect forty-five percent of board members.

Both Warren's and Sanders's plans are broadly similar to the German law on codetermination, which for many decades has allowed employees of large German corporations to elect up to half of all board members. It is therefore unsurprising that Senator Sanders points to Germany's successful economic development as evidence that economic progress and mandatory codetermination can go hand in hand.

However, this Article argues that codetermination promises to be a poor fit for U.S. corporations. While Germany arguably reaps significant benefits from codetermination, legal, social, and institutional differences between Germany and the United States make it highly unlikely that the United States would be able to replicate those benefits. Furthermore, the costs of codetermination probably would be much higher in the United States than they are in Germany.

* Ben H. and Kitty King Powell Chair in Business and Commercial Law, the University of Texas School of Law. For helpful comments and suggestions, we are grateful to Luca Enriques, Willy Forbath, Simon Jaeger, Ewan McGaughy, Konstantinos Sergakis, James Spindler, Wendy Wagner, and workshop participants at the Universities of Oxford and Texas. For excellent research assistance, we are indebted to Emilie Pagano.

** Chair for Commercial Law, The University of Oxford, and Professorial Fellow, St. Hugh's College, Oxford. 


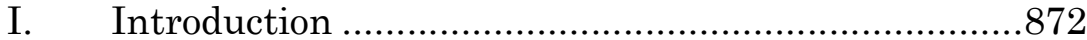

II. The German Law on Codetermination........................878

A. The 1976 Codetermination Act ..............................883

B. The One-Third Participation Act ..........................885

III. The Proposals by Senators Warren and Sanders......886

A. Scope of Application ............................................886

B. Board Composition ............................................ 888

IV. The Empirical Scholarship on Codetermination........889

A. Correlation Studies ........................................... 890

B. Difference-in-Differences...................................... 892

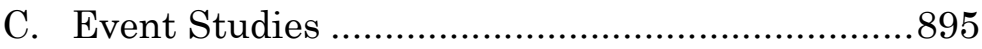

D. Instrumental Variables ........................................ 898

V. The Benefits of Codetermination..................................901

A. Collective Bargaining ..............................................901

B. Firm-Specific Investments .....................................903

C. Employee Interests...............................................906

VI. The Costs of Codetermination ......................................909

A. The Functioning of the Board ...............................909

B. Removal of Directors ...........................................913

C. Bankruptcy Governance......................................916

D. The Market for Corporate Control ........................919

E. Mandatory Corporate Law ....................................922

1. Preventing Circumvention..............................922

i. Reincorporation .......................................922

ii. Conversion ................................................927

iii. Corporate Charters and Bylaws...............929

2. The Cost of Preventing Regulatory Arbitrage.........................................................930

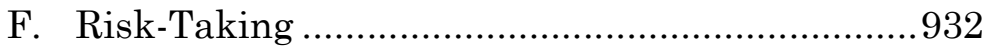

1. Codetermination and Risk-Taking...................932

2. Risk-Taking and Radical Innovation as a U.S. Specialty ...................................................935

VII. Conclusion 


\section{INTRODUCTION}

U.S. corporate law gives shareholders-and only shareholders - the right to elect corporate directors. 1 This governance arrangement is a natural choice if one subscribes to the idea that directors should put the interests of shareholders before those of other constituencies, a principle often referred to as shareholder primacy. ${ }^{2}$

Delaware courts and the vast majority of U.S. corporate law scholars endorse shareholder primacy as the lodestar of corporate law. ${ }^{3}$ Admittedly, a substantial minority of U.S.

1 See, e.g., Del. Code AnN. tit. 8, § 211(b) (2020) (providing that shareholders elect directors at the annual meeting or by written consent); MODEL Bus. CoRP. ACT $\S \S 8.03(c), 8.04$ (AM. BAR Ass'N 2002) (providing for director elections at shareholder meetings but permitting certain classes of shareholders to have special voting rights).

2 There are competing definitions of shareholder primacy. For example, it may refer to the duty to maximize shareholder wealth, or it may mean shareholders have "ultimate control." See Robert B. Thompson, AntiPrimacy: Sharing Power in American Corporations, 71 Bus. LAW. 381, 387 (2016) (contrasting these two meanings). There are also different understandings of the duty to maximize shareholder wealth. A particularly radical understanding of this duty might hold that directors and officers should manage the corporation solely for the benefit of shareholders to the exclusion of other interests. Much of the critique directed against shareholder primacy targets this narrow interpretation. See, e.g., Jill E. Fisch, Measuring Efficiency in Corporate Law: The Role of Shareholder Primacy, 31 J. CoRP. L. 637, 673-74 (2006) ("Existing legal doctrine and economic theory do not justify evaluating regulatory policy exclusively in terms of shareholder interests."). However, some scholars define shareholder primacy as requiring managers to put the interests of shareholders ahead of those of other constituencies. See, e.g., Stephen M. Bainbridge, In Defense of the Shareholder Wealth Maximization Norm: A Reply to Professor Green, 50 WASH. \& LEE L. REV. 1423, 1424 (1993).

3 For Delaware opinions taking this position, see, e.g., Malone v. Brincat, 722 A.2d 5, 9 (Del. 1998) ("The board of directors has the legal responsibility to manage the business of a corporation for the benefit of its shareholder owners.") (citing DEL. CoDE ANN. tit. 8, § 141(a)); Weinstein Enters. v. Orloff, 870 A.2d 499, 508-09 (Del. 2005) (stressing that the board of directors must manage the corporation's business for the shareholders' benefit). For observations on the academic landscape, see, e.g., Henry Hansmann \& Reinier Kraakman, The End of History for Corporate Law, 89 GEO. L.J. 439, 440-41 (2001) ("[There is] strong evidence of a growing 
scholars believe that corporate boards should put an increased focus on other interests, such as those of employees or society as a whole. ${ }^{4}$ Moreover, this view seems to have gained a firm place in corporate rhetoric. For example, 229 CEOs have

consensus.... [that] managers of the corporation should be charged with the obligation to manage the corporation in the interests of its shareholders[.]"); Ian B. Lee, Efficiency and Ethics in the Debate About Shareholder Primacy, 31 DEL. J. CoRP. L. 533, 535 (2006) (noting that "a nearly overwhelming chorus of academic voices endorsed 'shareholder primacy" in the recent past but identifying emerging opposition).

4 For example, Margaret Blair and Lynn Stout argue in favor of a "team production model" of corporate law-a concept originally advanced by Armen A. Alchian \& Harold Demsetz, Production, Information Costs, and Economic Organization, 62 AM. ECON. REV. 777, 779 (1972)-and claim that "boards exist ... to protect the enterprise-specific investments of all the members of the corporate 'team,' including shareholders, managers, [and] rank and file employees[.]" Margaret M. Blair \& Lynn A. Stout, A Team Production Theory of Corporate Law, 85 VA. L. REV. 247, 253 (1999). Cf. Lynn A. Stout, Response, The Toxic Side Effects of Shareholder Primacy, 161 U. PA. L. REV. 2003, 2022 (2013) (arguing that the losses that shareholder primacy imposes on non-shareholder constituents may outweigh its benefits to shareholders). Einer Elhauge, Sacrificing Corporate Profits in the Public Interest, 80 N.Y.U. L. REV. 733, 739-40 (2005), advances several reasons why it may be efficient to allow corporate boards to sacrifice some corporate profits for the benefit of society but does not question shareholders' rights to elect directors. David G. Yosifon, The Law of Corporate Purpose, 10 BERKELEY Bus. L.J. 181, 228 (2013), argues that boards should pay "good faith attention to the interests of multiple corporate stakeholders[.]" Cf. also David J. Berger, Reconsidering Stockholder Primacy in an Era of Corporate Purpose, 74 Bus. LAW. 659, 662 (2019) ("There is now a growing recognition that the model of stockholder primacy is no longer acceptable, and that corporations must focus on broader corporate purposes, beyond stockholder value."). For a historical account of employee influence on corporate governance in the United States, see Ewan McGaughey, Democracy in America at Work: The History of Labor's Vote in Corporate Governance, 42 SEATTLE U. L. REV. 697, 697 (2019) ("The United States has one of the world's strongest traditions of democracy at work."). For a decidedly critical view of stakeholder models of corporate governance, see Lucian A. Bebchuk \& Roberto Tallarita, The Illusory Promise of Stakeholder Governance, 106 CoRNELL L. REV. (forthcoming Dec. 2020) (manuscript at 67-68), https://papers.ssrn.com/sol3/papers.cfm? abstract_id=3544978 (on file with the Columbia Business Law Review) (arguing that stakeholderism, in addition to harming shareholders, also imposes substantial costs on stakeholders). 
signed a 2019 Business Roundtable resolution which provided that corporations should not only serve the interests of shareholders but also those of other constituencies. 5

However, even those scholars and CEOs that critique the shareholder primacy principle typically fail to call into question its corporate governance analog, namely the principle that shareholders are the only stakeholders that have the right to elect corporate directors. ${ }^{6}$ It is particularly remarkable, therefore, that two well-known liberal senators and erstwhile contenders for the Democratic presidential nomination, Bernie Sanders and Elizabeth Warren, have embraced the idea of giving employees of large corporations a voice in corporate governance. ${ }^{7}$

Under Senator Warren's Accountable Capitalism Act, which would apply to corporations with more than $\$ 1$ billion in annual gross receipts, a corporation's employees would elect forty percent of corporate directors. ${ }^{8}$ Senator Sanders's

5 Press Release, Bus. Roundtable, Business Roundtable Redefines the Purpose of a Corporation To Promote 'An Economy That Serves All Americans' (Aug. 19, 2019), https://www.businessroundtable.org/businessroundtable-redefines-the-purpose-of-a-corporation-to-promote-an-economythat-serves-all-americans [https://perma.cc/5DFS-CE5X]. The number of signatories continues to grow. See Statement on the Purpose of a Corporation, Bus. RoundTABLE (last updated Oct. 2020), https://s3.amazonaws.com/brt.org/BRT-

StatementonthePurposeofaCorporationOctober2020.pdf [https://perma.cc/XV7D-EQWG].

6 None the authors cited supra note 4 question the principle that shareholders alone should elect directors. See also Jeffrey N. Gordon, Addressing Economic Insecurity: Why Social Insurance Is Better than Corporate Governance Reform, The CLS BLUE Sky Blog (Aug. 21, 2019), https:/clsbluesky.law.columbia.edu/2019/08/21/addressing-economicinsecurity-why-social-insurance-is-better-than-corporate-governancereform/ [https://perma.cc/RR4N-CSB8] (advocating "for a kind of lifetime human potential insurance" and arguing that neither a "codetermination strategy" nor abolishing the shareholder primacy principle would address adequately economic insecurity).

7 See Accountable Capitalism Act, S. 3348, 115th Cong. § 6(b)(1) (2018); Bernie Sanders, Corporate Accountability and Democracy, BERNIE (last visited Sept. 7, 2020), https://berniesanders.com/issues/corporateaccountability-and-democracy/ [https://perma.cc/7BFJ-DTSG].

8 S. $3348, \S 6(\mathrm{~b})(1)$. 
proposal aims at corporations that are publicly traded or have assets or revenues of at least $\$ 100$ million. According to his proposal, these corporations' employees would elect forty-five percent of corporate directors. 9

One can advance several possible justifications for codetermination. Some proponents of codetermination argue in favor of the system on dignitary grounds, asserting that codetermination is necessary to preserve the dignity of employees, who ought to be more than mere cogs in the machinery of large corporations. 10 Alternatively, one can defend codetermination on grounds of distributive justice or fairness. In other words, one can argue that codetermination is necessary to ensure that employees receive their fair share of the wealth created by corporations. 11 Furthermore, one can focus on the political process and ask whether codetermination can help protect the democratic state against excessive corporate power. 12

9 Sanders, supra note 7.

10 The enactment of Germany's 1976 Codetermination Act followed the work of the Commission on Codetermination, which submitted a report on Germany's prior experience with codetermination. See Mitbestimmung im Unternehmen [Codetermination in the Corporation], Deutscher Bundestag: Drucksachen [BT]VI/334,

http://dipbt.bundestag.de/doc/btd/06/003/0600334.pdf

[https://perma.cc/Y578-AH8K] (Ger.). At the time, proponents of qualified codetermination felt that corporations-particularly large ones-still treated employees as mere cogs in a wheel, which they believed was inconsistent with human dignity. Id. at 18.

11 Cf. Lowell Gallaway, The Economic Consequences of Codetermination on Employment and Income Distribution, in THE Codetermination Movement In the West 169, 170 (Svetozar Pejovich ed., 1978) (noting that one of the "standard arguments" in support of "worker voice in business decisions" is that it can result in "a more equitable division of wealth, income, and influence" (internal quotation marks omitted) (quoting Eur. Cmtys. Comm'n, Employee Participation and Company Structure in the European Community, at 56 (Nov. 12, 1975))).

12 See Jens Dammann \& Horst Eidenmüller, Taming the Corporate Leviathan: Codetermination and the Democratic State 6-7 (Eur. Corp. Governance Inst. Working Paper No. 536/2020, Nov. 2020),

https://papers.ssrn.com/sol3/papers.cfm?abstract_id=3680769 (on file with the Columbia Business Law Review) (arguing that codetermination can play an important role in protecting democratic institutions). 
This Article, however, focuses on the economics of codetermination. It asks whether the economic costs of codetermination, if introduced in the United States, would outweigh its economic benefits. 13 Crucially, these costs and benefits include not just those accruing to shareholders but also those imposed on or enjoyed by other constituencies, most notably employees. Further, some costs and benefits-such as the potential satisfaction that employees may derive from having a say in how a corporation operates-may be hard to quantify in monetary terms. But this should not lead one to ignore these costs and benefits.

A plausible analog to Senators Warren's and Sanders's proposals is the German system of mandatory "parity codetermination,"14 which allows employees of firms with more than 2,000 employees to elect half of all board members. 15 The Warren and Sanders proposals resemble parity codetermination regarding the share of board seats that they assign to employee representatives. Moreover, Germany is the largest Western economy to assign a substantial number of board seats to employee representatives, 16 which makes it tempting to extrapolate

13 Hence, we apply a cost-benefit standard as a benchmark to judge the merits of codetermination. Cost-benefit analysis relies on the so-called Kaldor-Hicks test for judging the welfare effects of policy measures. According to this test, a measure increases overall efficiency if the "winners" under the measure could compensate the "losers" (i.e., could make them whole) and still enjoy a residual benefit. See HoRST EIDENMÜLLER, EFFIZIENZ ALS RECHTSPRINZIP: MÖGLICHKEITEN UND GRENZEN DER ÖKONOMISCHEN Analyse des Rechts [Efficiency as a Legal Principle: Possibilities AND LiMITS OF THE ECONOMIC ANALYSIS OF THE LAW] 51 (4th ed. 2015).

14 The term "parity codetermination" is common in the literature. See, e.g., Mark J. Roe, Political Preconditions to Separating Ownership from Corporate Control, 53 Stan. L. REV. 539, 547 (2000); Vahid Dejwakh, The Directorist Model of Corporate Governance: Why a Dual Board Structure for Public Corporations Is Good for Shareholders, Entrepreneurs, Employees, Capitalism, and Society, 8 WM. \& MARY PoL'Y REV., no. 1, 2016, at 37.

15 See infra Section III.A.

16 Of the largest European economies-Germany, the United Kingdom, France, Spain, and Italy-only France and Germany have embraced codetermination, and in France, employees may elect one or at most two directors. See infra Part III tbl.1. 
from the German experience. In fact, Senator Sanders explicitly invokes German codetermination as a model, pointing out that his proposal is "similar to what happens under 'employee co-determination' in Germany, which long has had one of the most productive and successful economies in the world."17

This Article therefore analyzes the prospects for codetermination in the United States by considering the German experience. While codetermination may offer substantial economic benefits at relatively low costs in Germany, we argue that there are compelling reasons to think that it would be a poor fit for the United States, at least as long as other institutional, legal, and economic differences between the two economies persist.

Drawing on the economic theory underlying codetermination, we show that many of the core benefits that Germany reaps from codetermination are much less likely to materialize in the United States. ${ }^{18}$ Additionally, the costs of codetermination likely would be much more substantial in the United States than in Germany.19 While mandatory codetermination may well be an efficient and desirable regime for Germany, the United States probably would suffer a welfare loss by following in Germany's footsteps.

The argument we present in this Article comes with two important caveats. First, we disregard the question of whether codetermination might be desirable for non-economic reasons, an issue that we explore in other work. 20 Second, we concede that some of the structural differences between the United States and Germany, to which we point in this Article, could diminish over time. For example, the United States could accord a much more central role to collective bargaining, move from a corporate law system that consists largely of default rules to one relying heavily on mandatory law, or reduce the role of capital markets in financing firms and

\footnotetext{
17 Sanders, supra note 7.

18 See infra Part V.

19 See infra Part VI.

20 See Dammann \& Eidenmüller, supra note 12.
} 
instead rely more heavily on bank financing. If these and other changes were to occur, codetermination might be as good a fit for American firms as it is for German firms. We assume, however, that it is highly unlikely the United States will fundamentally reshape its business institutions, law, and economy in the foreseeable future. Therefore, for the purpose of our current analysis, we disregard the possibility of these changes.

This Article is structured as follows. Part II summarizes the German law on codetermination. Part III highlights the differences between the German rules on codetermination and the proposals by Senators Sanders and Warren. Part IV analyzes the economic scholarship on the impact of Germany's codetermination regime on firm productivity, wages, and shareholder wealth and shows that the results are, by and large, inconclusive. Part V argues that if the United States were to adopt a mandatory codetermination regime, U.S. corporations and workers would be unlikely to reap some of the core benefits that codetermination yields in Germany. Part VI addresses the potential costs of codetermination and demonstrates that these would likely be much higher in the United States than they are in Germany.

\section{THE GERMAN LAW ON CODETERMINATION}

Laws on board-level worker participation exist in many jurisdictions, most of them in Europe.21 But the German codetermination regime stands out for two reasons. First, Germany is, by far, the largest Western economy to reserve a substantial number of board seats to employee representatives. Second, the "German model" is particularly far-reaching in that it reserves half of all board seats at the

21 See Board-Level Representation, WORKER-PARTICIPATION.EU (last visited Mar. 12, 2020) http://www.worker-participation.eu/NationalIndustrial-Relations/Across-Europe/Board-level-Representation2

[https://perma.cc/9NKV-R4AW]. Outside of Europe, China has adopted codetermination based on the German regime. Tom C. Hodge, The Treatment of Employees as Stakeholders in the European Union: Current and Future Trends, 38 SyRACUSE J. INT'L L. \& CoM. 91, 102 (2010). 
largest corporations to employee representatives.22 Perhaps for these reasons, Germany's codetermination regime often serves as a prototype 23 or, at least, as a reference point for alternative policy proposals. 24

The current German law on codetermination mainly relies on two statutes 25: the 1976 Codetermination Act26 and the 2004 One-Third Participation Act.27

22 Cf. Franklin Allen, Elena Carletti \& Robert Marquez, Stakeholder Governance, Competition, and Firm Value, 19 REV. Fin. 1315, 1316 (2015) (calling Germany "[t]he most striking example" of a stakeholder model).

23 Cf. Cynthia Estlund, Will Workers Have a Voice in China's "Socialist Market Economy"? The Curious Revival of the Workers Congress System, 36 COMPAR. LAB. L. \& POL’Y J. 69, 89 (2014) ("[T]he German [Works Council] system is recognized as a 'prototype' within Europe and is relatively familiar outside Europe.”).

24 See, e.g., Andreas Kokkinis \& Konstantinos Sergakis, A Flexible Model for Efficient Employee Participation in UK Companies, 20 J. CORP. L. STUD. 453, 455 (2020) (arguing for a more flexible model of employee participation than the German model of codetermination).

25 The German law on codetermination involves other statutes as well, but they are of marginal importance to this Article. In particular, Germany has a special codetermination statute governing stock corporations in the coal and steel industry: the Coal and Steel Codetermination Act of 1951. See Gesetz über die Mitbestimmung der Arbeitnehmer in den Aufsichtsräten und Vorständen der Unternehmen des Bergbaus und der Eisen und Stahl erzeugenden Industrie [Law on the Participation of Workers in the Supervisory Boards and Managing Boards of Companies in the Coal, Iron, and Steel Industries], May 21, 1951, BundesgesetzBlatt, TeIL I [BGBL I] at 341, last amended by Gesetz [G], Apr. 24, 2015, BGBL I at 642, art. 5 (Ger.). For a summary of this statute, see Jens C. Dammann, Note, The Future of Codetermination After Centros: Will German Corporate Law Move Closer to the U.S. Model?, 8 FordHAM J. CoRP. \& Fin. L. 607, 619-20 (2003). For a historical analysis of the German codetermination regime, see generally Ewan McGaughey, The Codetermination Bargains: The History of German Corporate and Labor Law, 23 CoLuM. J. EUR. L. 135 (2016).

26 Gesetz über die Mitbestimmung der Arbeitnehmer [MitbestG] [Codetermination Act], May 4, 1976, BGBL I at 1153, last amended by Gesetz [G], Apr. 24, 2015, BGBL I at 642, art. 7 (Ger.).

27 Zweites Gesetz zur Vereinfachung der Wahl der Arbeitnehmervertreter in den Aufsichtsrat [One-Third Participation Act], May 18, 2004, BGBL I at 974, art. 1 (Ger.). 
Table 1. Board-Level Codetermination and Board Structure in European Countries

\begin{tabular}{|c|c|c|c|c|c|}
\hline Country & Perecentage & Board & Country & Percentage & Board \\
\hline Austria & $1 / 3$ & $\begin{array}{l}\text { Two- } \\
\text { tier }\end{array}$ & Hungary & $1 / 3$ & Either \\
\hline Croatia & 1 rep. & Either & Luxembourg & $1 / 3$ & $\begin{array}{l}\text { One- } \\
\text { tier }\end{array}$ \\
\hline $\begin{array}{l}\text { Czech } \\
\text { Republic }\end{array}$ & $1 / 3$ & $\begin{array}{l}\text { Two- } \\
\text { tier }\end{array}$ & Norway & $1 / 3$ & $\begin{array}{l}\text { Two- } \\
\text { tier }\end{array}$ \\
\hline Denmark & $1 / 3$ & $\begin{array}{l}\text { Two- } \\
\text { tier }\end{array}$ & Slovakia & $1 / 3$ & $\begin{array}{l}\text { Two- } \\
\text { tier }\end{array}$ \\
\hline Finland* & $1 / 4$ & Either & Slovenia & $1 / 2$ & Either \\
\hline France $^{* *}$ & 1 rep. & Either & Sweden & 3 reps. ${ }^{* * *}$ & $\begin{array}{l}\text { One- } \\
\text { tier }\end{array}$ \\
\hline Germany & $1 / 2$ & $\begin{array}{l}\text { Two- } \\
\text { tier }\end{array}$ & & & \\
\hline
\end{tabular}

Note: this table displays the maximum number of employee representatives that must be included on corporate boards. If that percentage differs depending on a corporation's size, we focus on the largest corporations. We disregard special rules for particular industries or for companies fully or partially owned by the government. This table does not include the Netherlands, which relies on a peculiar version of codetermination: in statutorily defined "large companies," the works council has the right to nominate one-third of supervisory board members. *In Finland, the number of employee representatives depends on negotiations between management and workers. Absent agreement, however, the employees are entitled to elect one-fourth of all board members. ** In France, employees have the right to elect one board member, but that board member only has an advisory function. ** In Sweden, the law allows employees at companies with more than 1,000 employees to elect three representatives to the corporate board. However, the shareholders can determine the total number of board members and can therefore determine the fraction of employee representatives. In practice, about one-third of board members tend to be 
employee representatives. Sources for the various national rules on codetermination 28 and board structure 29 appear in the footnotes.

28 Austrian law allows employees of stock corporations to elect onethird of the supervisory board's members. Gesetz VOM 15. MAI 1919, BETREFFEND DIE ERRICHTUNG VON BETRIEBSRÄTEN [WORKS COUNCIL ACT OF May 15, 1919] StaAtsgesetzBlatt [STGBL] No. 283/1919, § 3(11) (on file with Columbia Business Law Review) (Austria) (initiating the participatory scheme). Croatian law allows employees of stock corporations to elect one board member. Maja Ključar, Unternehmensmitbestimmung der Arbeitnehmer in Kroatien [Employee Codetermination in Croatia], 14 WIRTSCHAFT UND RECHT IN OSTEUROPA [WiRO] 359, 361 (2005) (Ger.). Czech law allows employees at stock corporations with at least 500 employees to elect one-third of all supervisory board members. L. Fulton, Board-Level Representation, worker-participation.eu (last updated 2020), http://www.worker-participation.eu/National-Industrial-

Relations/Countries/Czech-Republic/Board-level-Representation

[https://perma.cc/NR3C-V6Z6]. In Denmark, employees at stock corporations with at least 30 employees have the right to elect one-third of all supervisory board members. FELIX HöRISCH, UNTERNEHMENSMITBESTIMMUNG IM NATIONALEN UND INTERNATIONALEN Vergleich [A COMPARATIVE AND International Perspective ON CODETERMinATION] 33 (2009). In Finland, employees of firms with at least 150 employees are entitled to negotiate board representation. Id. at 34. If these negotiations fail, employees are entitled to elect one employee representative for every four shareholder representatives, but the minimum number of employee representatives is one and the maximum number is four. $I d$. The employer can choose whether codetermination applies to the managing board or the supervisory board. Id. In France, employees at stock corporations with at least 1,000 employees in France or 5,000 employees globally have the right to elect one board member. CODE DE COMMERCE [C. COM.] [COMMERCIAL CODE] art. L225-27-1(II) (Fr.). The number of employee board representatives increases from one to two if the board has eight or more members. Id.; see also Loi 2019-486 du 22 mai 2019 relative à la croissance et la transformation des entreprises [Law 2019-486 of May 22, 2019 Relating to the Growth and Transformation of Business] JOURNAL

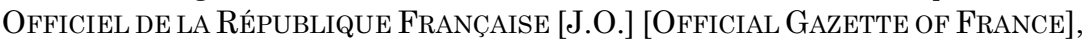
No. 0119, art. 184(5)(b) (replacing the word "twelve" with the word "eight"). In Germany, employees at corporations with more than 2,000 employees elect half of the members of the supervisory board. Codetermination Act $\S$ 29(2). In Hungary, the situation is more complicated because it depends on whether a stock corporation has a one-tier or a two-tier board structure. Hungary's 2006 Business Corporation Act allows single-tier boards as well as two-tier boards and makes codetermination optional in companies with single-tier boards. László Neumann, Board-Level Employee Representation in Hungary: A Useful Tool for Company Unions and Works Councils, in 
European BoARD-LEVEL EMPLOYEe RePRESENTATION 103, 108 (Jeremey Waddington ed., 2018). By contrast, employees of a stock corporations with a two-tier board structure and at least 200 employees by default have the right to elect one-third of the corporation's supervisory board members. Id. However, even in corporations with a two-tier board structure, the corporation can opt out of codetermination, albeit only if the corporation's works council approves. Id. In Luxembourg, employees at corporations with at least 1,000 employees have the right to elect one third of all supervisory board members. Valérie Raynaud, Employees' Co-Determination in Luxembourgian Companies, in EMPLOYEES' CO-DETERMINATION IN THE Member States of the European Union 63, 67 (Theodor Baums \& Peter Ulmer eds., 2004). In the Netherlands, employees at corporations with at least 100 employees have the right to nominate one-third of all supervisory board directors. E.g., Loyens \& Loeff, Management and Supervisory Boards in the Netherlands in Brief 51 (2019) (on file with the Columbia Business Law Review). For a detailed explanation of the peculiar procedure governing the appointment of Dutch supervisory board members see Levinus Timmerman \& Salco-Jan Spanjaard, Arbeitnehmermitbestimmung in den Niederlanden [Codetermination in the Netherlands], in EMPLOYEECodetermination in the Member States of the European Union, supra, at 75, 85-86. In Norway, employees at corporations with thirty to forty-nine employees have the right to elect one board member, and corporations with fifty or more employees have the right to elect one-third of all board members. Inger Marie Hagen, Norwegian Board-Level Employee Representatives: Still in a Prominent Position?, in EuROPEAN BOARD-LEVEL EMPLOYEe REPRESENTATION, supra, at 119, 123-24. In the Slovak Republic, employees in stock corporations with at least fifty employees elect one-third of all supervisory board members. L. Fulton, Board-Level Representation, WORKER-PARTICIPATION.EU (last updated 2013), http://www.workerparticipation.eu/National-Industrial-Relations/Countries/Slovak-

Republic/Board-level-Representation [https://perma.cc/DE8J-JGTS] [hereinafter Fulton, Slovak Republic]. In Slovenia, employees at corporations with at least 500 employees elect one-third of all board members. HöRISCH, supra, at 41; Valentina Franca, Board-Level Employee Representation in Slovenia: From the Constitution to Practice, in EUROPEAN BoARD-Level Employee Representation, supra, at 143, 143. In Sweden, employees at corporations with at least twenty-five employees have the right to elect two board members, and employees at corporations with at least 1,000 employees have the right to elect three board members. Fredrik Movitz \& Johanna Palm, Board-Level Representation in Sweden: A Neglected Aspect of the Swedish Model?, in EUROPEAN BOARD-LEVEL EMPLOYEE REPRESENTATION, supra, at 179, 184.

29 Austrian stock corporations have a two-tier board structure. BundeSGESETZ VOM 31 MÄRZ 1965 ÜBER AKTIENGESELLSCHAFTEN [AKTIENGESETZ 1965] [STOCK CORPORATION ACT OF 1965] BundeGESETZBLATT 


\section{A. The 1976 Codetermination Act}

German stock corporations have a mandatory two-tier board structure consisting of a managing board and a supervisory board. The managing board is in charge of day-today operations. 30 The supervisory board appoints the members of the managing board, 31 monitors the managing

[BGBL] No. 98/1965, $\S \S 70,86$. Croatian stock corporations have a two-tier board structure. See Klaus J. Hopt, Comparative Corporate Governance: The State of the Art and International Regulation, 59 AM. J. COMPAR. L. 1, 72 n.107 (2011). Stock corporations in the Czech Republic can choose between a one-tier system and a two-tier system, though the two-tier system is the legal default. Petr Bohata, Tschechische Republik: Gesetz über Korporationen-Teil 6: Aktiengesellschaft [Czech Republic: Corporation Act-Part 6: Stock Corporations], 22 WIRO 17, 18-19 (2013). In Denmark, the law on stock corporations mandates a two-tier system. Cynthia Van Hulle, On the Nature of European Holding Groups, 18 INT'L REV. L. \& ECON. 255, 258 n.3 (1998). In Finland, stock corporations can choose between a one-tier board structure and a two-tier board structure. Hanjo Hamann, Unpacking the Board: A Comparative and Empirical Perspective on Groups in Corporate Decision-Making, 11 BeRKeley Bus. L.J. 1, 12 (2014). Stock corporations in France also have the choice between a one-tier board structure and a two-tier board structure. Hamann, supra, at 12-13. Stock corporations in Germany have a two-tier board structure. Aktiengesetz [AktG] [Stock Corporation Act], Sept. 6, 1965, BGBL I at 1089, $\S \S 76(1), 95$, last amended by Gesetz [G], July 17, 2017, BGBL I at 2446, art. 9 (Ger.). In Hungary, stock corporations have the choice between a one-tier structure and a two-tier structure. See Neumann, supra note 28, at 108. The law governing stock corporations in Luxembourg adheres to a one-tier structure. Van Hulle, supra note 28, at 258. Norwegian stock corporations have a one-tier board structure. Hagen, supra note 28, at 121 (noting that a Norwegian board combines monitoring and supervisory functions). In the Slovak Republic, stock corporations have a two-tier board structure. Fulton, Slovak Republic, supra note 28. In Slovenia, stock corporations can choose between a one-tier and a two-tier system, although the vast majority of corporations have a two-tier board structure. Franca, supra note 28, at 161. In Sweden, the law on stock corporations provides for a two-tier system. Movitz \& Palm, supra note 28, at 185.

30 Stock Corporation Act $\S 76(1)$.

31 Id. $\S 84(1)$. 
board's work, 32 and has the power to remove managing board members for cause. 33

Under Germany's main codetermination statute, the 1976 Codetermination Act, shareholders elect half of the members of the supervisory board and employers elect the other half. 34 It is therefore common to speak of this system as "parity codetermination." However, the balance tilts slightly in favor of the shareholders: if the board is deadlocked, the chairperson of the board holds the swing vote. 35 This rule tends to give an edge to the shareholder representatives because, if the board cannot agree on a chairperson, the shareholder representatives elect the chairperson. 36

Moreover, the German Codetermination Act does not treat employees as a monolithic group. Rather, at least one of the workers' representatives must be a managerial employee. ${ }^{37}$ As a result, the employee representatives may not represent identical interests and may not always vote as a block. 38

German stock corporations are subject to the 1976 Codetermination Act if they have more than 2,000

$32 \quad$ Id. $\S 111(1)$.

33 Id. $\S 84(3)$.

34 Gesetz über die Mitbestimmung der Arbeitnehmer [MitbestG] [Codetermination Act], May 4, 1976, BGBL I at $1153 \S 7(1)$, last amended by Gesetz [G], Apr. 24, 2015, BGBL I at 642, art. 7 (Ger.). Only German employees can stand for election, and only German employees have the right to vote, even in German companies with a clear majority of non-German employees. Whether this is compatible with European anti-discrimination laws is questionable. See generally Deutsche Mitbestimmung unter EUROPÄISCHEM REFORMZWANG (MATHIAS HABERSACK ET AL. EDS., 2016). The Court of Justice of the European Union (CJEU) nevertheless upheld the German rules in a landmark judgment in 2017. See Case C-566/15, Erzberger v. TUI AG, ECLI:EU:C:2017:562, ๆ 42 (July 18, 2017).

35 Codetermination Act $§ 29(2)$.

36 Id. $\S 27(2)$. Against this background, some scholars prefer to use the term "quasi-parity codetermination" in connection with the 1976 Codetermination Act. See, e.g., Mariana Pargendler, The Grip of Nationalism on Corporate Law, 95 IND. L.J. 533, 545 (2020).

37 Codetermination Act $\S 11(2)$.

38 See, e.g., Henry Hansmann, Worker Participation and Corporate Governance, 43 U. TORONTO L.J. 589, 602 (1993) (noting that managerial employees may side with management). 
employees. 39 A different statutory regime applies to firms in the coal and steel industries. 40 Charitable, political, and news organizations are exempt. 41

Privately held firms typically incorporate as limited liability companies (LLCs), or Gesellschaften mit beschränkter Haftung (GmbHs). 42 The 1976 Codetermination Act applies to LLCs as well, as long as they have more than 2,000 employees. 43 Unlike stock corporations, LLCs do not, by default, have a two-tier board structure. ${ }^{44}$ However, a LLC subject to the 1976 Codetermination Act must have both a managing board and a supervisory board. 45

\section{B. The One-Third Participation Act}

Companies with 2,000 or fewer employees do not fall under the 1976 Act. 46 However, the 2004 One-Third Participation

39 Codetermination Act $\S 1(1)(2)$.

40 Gesetz über die Mitbestimmung der Arbeitnehmer in den Aufsichtsräten und Vorständen der Unternehmen des Bergbaus und der Eisen und Stahl erzeugenden Industrie [MontanMitbestG] [Law on the Participation of Workers in the Supervisory Boards and Managing Boards of Companies in the Coal, Iron, and Steel Industries], May 21, 1951, BGBL I at 341, last amended by Gesetz [G], Apr. 24, 2015, BGBL I at 642 (Ger.).

41 Codetermination Act $\S 1(4)$.

42 Statistisches Bundesamt, Umsatzsteuerstatistik (Voranmeldungen); Steuerpflichtige und deren Lieferungen und Leistungen nach der Rechtsform [Statistics (Advance Registrations); Taxable Persons and Entities and their Products and Services by Legal Form], Destatis (last updated Mar. 24, 2020),

https://www.destatis.de/DE/Themen/Staat/Steuern/Umsatzsteuer/Tabellen /voranmeldungen-rechtsformen.html [https://perma.cc/GR3G-GYX4] (reporting that in 2018 the number of Aktiengesellschaften [stock corporations] filing tax returns was 7,777 whereas the number of $\mathrm{GmbHs}$ [limited liability companies] filing tax returns was 544,738).

43 Codetermination Act $\S 1(1)$.

44 Gesetz betreffend die Gesellschaften mit beschränkter Haftung [GmbHG] [Limited Liability Companies Act], Apr. 20, 1892, RGBL [REICHSGESETzBLATT] at 477, §52, last amended by Gesetz [G], July 17, 2017, BGBL I at 2446, art. 10 (Ger.) (providing which rules apply if the articles of organization call for the creation of a supervisory board).

45 Codetermination Act $\S 6(1)$.

46 See id. $\S 1(1)(2)$. 
Act may cover them. 47 The One-Third Participation Act applies to corporations and LLCs that have at least 500 employees. 48 It gives employees the right to elect one-third of a company's supervisory board members, ${ }^{49}$ so it is less farreaching than the 1976 Act.

\section{THE PROPOSALS BY SENATORS WARREN AND SANDERS}

Senators Warren's and Sanders's proposals are similar to Germany's 1976 Codetermination Act. However, this should not divert attention from significant differences. As we discuss below, these differences relate primarily to the number of firms - and less to the number of employees - covered by the proposals.

\section{A. Scope of Application}

Perhaps the most obvious differences between the senators' proposals and German law concern the proposals' scopes. Senator Warren's bill would apply to corporations and LLCs as long as they engage in interstate commerce and have more than $\$ 1$ billion in gross receipts. 50 Senator Sanders's proposal targets publicly-traded corporations with at least $\$ 100$ million in annual revenues or $\$ 100$ million in total assets. 51 By contrast, the 1976 Codetermination Act applies whenever a company or $\mathrm{GmbH}$ has more than 2,000 employees. 52

These different criteria could lead to vastly different outcomes. Table 2 illustrates this point by applying the three approaches to public corporations headquartered in the United States and included in Standard \& Poor's

47 Zweites Gesetz zur Vereinfachung der Wahl der Arbeitnehmervertreter in den Aufsichtsrat [One-Third Participation Act], May 18, 2004, BGBL I at 974, art. 1 (Ger.).

$48 \quad$ Id. $\S 1(1)$.

49 Id. at $\S 4(1)$.

50 Accountable Capitalism Act, S. 3348, 115th Cong. § 2(2) (2018).

51 Sanders, supra note 7.

52 See supra notes 42-43 and accompanying text. 
Compustat-a database commonly used for empirical research in economics and finance.53 For the purpose of this exercise, we treat U.S. corporations and LLCs as equivalents to German stock corporations (Aktiengesellschaften) and GmbHs, respectively.

Compustat relies on data from companies' financial statements filed with the Securities and Exchange Commission. Therefore, Compustat does not include closely held firms, and, accordingly, Table 2 only highlights the differences between the various approaches for publiclytraded firms. Even for these firms, however, the differences regarding the number of firms covered are substantial. Senator Sanders's plan applies to all 3,437 public corporations headquartered in the United States and included in the database for the year 2019, the most recent year for which data are available. By contrast, Senator Warren's Accountable Capitalism Act would cover about forty percent fewer companies, as would the 1976 Codetermination Act. The differences become smaller, however, if the focus is on the number of employees, the combined market capitalization, or the assets of covered firms. This is because the large public corporations that are within the scope of all three plans account for the bulk of employees, market capitalization, and assets.

Table 2. Coverage of Public Corporations (2019)

\begin{tabular}{lc|c|c|c}
\hline & \multicolumn{2}{l}{$\begin{array}{l}\text { Number of } \\
\text { Companies }\end{array}$} & $\begin{array}{l}\text { Employees } \\
\text { (millions) }\end{array}$ & \multicolumn{2}{l}{$\begin{array}{l}\text { Market } \\
\text { Capitalization } \\
\text { (trillions of } \\
\text { USD) }\end{array}$} & $\begin{array}{l}\text { Assets } \\
\text { (trillions of } \\
\text { USD) }\end{array}$ \\
\cline { 2 - 5 } Sanders & 3,437 & 31.47 & 29.9 & 45.3 \\
\hline Warren & 1,237 & 29.56 & 27.9 & 42.3 \\
\hline 1976 Act & 1,349 & 30.55 & 27.4 & 40.8 \\
\hline
\end{tabular}

53 We disregard the "interstate commerce" requirement contained in the Accountable Capitalism Act, Accountable Capitalism Act, S. $3348 \S$ 2(2)(A)(ii), since Compustat data do not allow us to ascertain whether a firm meets this requirement. However, as a practical matter it is safe to assume that the vast majority of publicly-traded corporations do not limit their businesses to one state. 
Note: We drop partnerships and trusts as well as entities headquartered or incorporated outside the United States. The numbers for the Warren proposal and the 1976 Act include LLCs, but those for the Sanders proposal do not. We use the Compustat variable "total revenues" to capture gross receipts (Warren) and total revenues (Sanders). 54

The policy goals underlying differing scopes are not always obvious. If one assumes that the main purpose of codetermination is to protect employees, the German approach, which focuses on the number of employees, is perhaps the most intuitive: a greater number of employees means that there are more people who need protection. We suspect that Senator Warren's proposal focuses on gross receipts mainly because they are readily apparent from a corporation's tax return. Similarly, Senator Sanders's focus on annual revenues, total assets, and a firm's status as a public corporation may partially be motivated by ease of administration. In addition, a switch to mandatory codetermination is bound to trigger substantial compliance costs, and a corporation's gross receipts or total assets may be an indicator of that corporation's ability to shoulder these costs.

\section{B. Board Composition}

The U.S. proposals also differ from German codetermination law with respect to their impact on corporate boards. Part of the difference pertains to the general structure of boards. Germany traditionally has relied on a two-tier board structure for public corporations. The management board is responsible for the day-to-day management of the corporation 55 and the supervisory board for the supervision of

54 We only include firm observations for which the Compustat variables employees ("emp"), total assets ("at"), market capitalization ("prcc_f" * "csho"), and total revenues ("revt") are available. Excluding firms that lack data on employees, total assets, market capitalization, and total revenuesin this order-reduces the dataset by 446, 0,1 , and 7 observations, respectively.

55 Aktiengesetz [AktG] [Stock Corporation Act], Sept. 6, 1965, BGBL I at $1089, \S 76(1)$, last amended by Gesetz [G], July 17, 2017, BGBL I at 2446, 
the management board. 56 German codetermination law only requires that one of the two boards, namely the supervisory board, includes employee representatives. 57 By contrast, U.S. corporations have a one-tier board structure, and the codetermination proposals of Senators Sanders and Warren do not purport to change this structure. Hence, if implemented, codetermination would impact directly the management of U.S. corporations.

Moreover, it is important to note that the two U.S. proposals differ slightly from German law with respect to the number of employee representatives. The 1976 Codetermination Act allows employees to elect fifty percent of the supervisory board members, 58 whereas Senator Warren's plan calls for employees to elect forty percent, 59 and Senator Sanders' plan forty-five percent. 60

\section{THE EMPIRICAL SCHOLARSHIP ON CODETERMINATION}

Germany's relative economic success 61 suggests that, at the very least, codetermination is not an insurmountable

art. 9 (Ger.) (providing that the managing board is responsible for managing the corporation).

56 Id. $\S 111(1)$ (providing that the supervisory board monitors the corporation's management).

57 Gesetz über die Mitbestimmung der Arbeitnehmer [MitbestG] [Codetermination Act], May 4, 1976, BGBL I at $1153 \S 7(1)$, last amended by Gesetz [G], Apr. 24, 2015, BGBL I at 642, art. 7 (Ger.).

58 Id.

59 Accountable Capitalism Act, S. 3348, 115th Cong. § 6(b)(1) (2018).

60 Sanders, supra note 7.

61 As of 2019, Germany's GDP per capita was $\$ 46,258.90$, placing it ahead of most major economies, including, for example, Canada $(\$ 46,194.70)$; France $(\$ 40,493.90) ;$ Japan $(\$ 40,246.90)$, South Korea $(\$ 31,762)$, and the United Kingdom $(\$ 42,300.30)$, though well behind the United States $(\$ 65,118.40)$ and Switzerland $(\$ 81,993.70)$. GDP Per Capita (Current US\$), THE WORLD BANK tbl.All Countries and Economies (last visited Nov. 5, 2020),

https://data.worldbank.org/indicator/NY.GDP.PCAP.CD [https://perma.cc/2DSE-XV5D]. 
obstacle to prosperity. 62 But the question remains whether German firms would be doing even better without codetermination. Since the enactment of the 1976 Codetermination Act, numerous empirical studies have sought to analyze the impact of codetermination on shareholder wealth, firm productivity, wages, and job security. However, as shown in the following section, many of the existing studies face substantial methodological challenges, and different studies have yielded vastly different results. In that sense, the empirical literature remains inconclusive. Furthermore, a key question is to what extent empirical results based on European data can be extrapolated to the United States, a question that we discuss in subsequent sections.

\section{A. Correlation Studies}

Many early studies on codetermination looked for correlations between codetermination and variables such as firm performance or wages. 63 For example, in a seminal paper

62 See Klaus J. Hopt, Labor Representation on Corporate Boards: Impacts and Problems for Corporate Governance and Economic Integration in Europe, 14 INT'L REV. L. \& ECON. 203, 206 (1994) (noting that even though the success of codetermination is unclear, "the prognosis of dramatic systemic consequences has proved wrong").

63 See, e.g., Larry Fauver \& Michael E. Fuerst, Does Good Corporate Governance Include Employee Representation? Evidence from German Corporate Boards, 82 J. FIN. EcON. 673, 686 (2006) (using a sample of 786 publicly-traded German firms, 400 of which have employee representatives on their boards, and finding that codetermination is associated with a higher Tobin's q, a measure of a firm's value over its costs); Gary Gorton \& Frank A Schmid, Capital, Labor, and the Firm, 2 J. EuR. ECON. Ass'N 863, 895 (2004) (focusing on 250 large German public corporations and finding that firms subject to parity codetermination have a 31\% lower market-tobook ratio than firms with one-third codetermination). Andreas Bermig, German Supervisory Board Size and Composition - a Detailed Evaluation of Their Effects on Performance, Earnings Management and Cash Holdings (Dec. 2012) (Ph.D. dissertation, Universität Paderborn) (on file with the Columbia Business Law Review), runs fixed effects regressions using panel data on 294 firms for the years 1998 to 2007. He finds no statistically significant evidence that the share of union representatives or employee representatives correlates positively or negatively with Tobin's q. See id. at 
from 2004, Gary Gorton and Frank Schmid showed that parity codetermination was associated with an average thirty-one percent decline in firms' market-to-book ratio compared to one-third codetermination. 64

The obvious problem with studies like Gorton and Schmid's is that correlation does not imply causation. Instead, observed correlations may be due to variables that are unobserved and therefore omitted from the relevant econometric models, a problem known as "omitted variable bias."65 This problem is particularly conspicuous in the context of codetermination: to fall under the 1976 Codetermination Act, a firm must have more than 2,000 employees, 66 and there are reasons why some firms have more employees than others. A company that can automate much of its production, for example, may be able to reduce the number of its workers and thereby increase its profitability. 67 Thus, the ability to automate may be an omitted variable that causes a firm's stock price (and hence its market-to-book ratio) to rise while also leading to a decline in the number of employees, thereby preventing the application of the 1976 Codetermination Act. In this example, a negative correlation between parity codetermination and market-to-book ratio may result, but that correlation does not imply that codetermination causes a decrease in book value. 68

135 fig.9. Although Bermig finds that the share of independent employee representatives is negatively associated with Tobin's q, that finding is only significant at the $10 \%$ level. $I d$.

64 See Gorton \& Schmid, supra note 63, at 879.

65 For a useful introduction to the problem of omitted variable bias, see, Joshua D. Angrist \& JÖRn StefFen Pischke, Mostly Harmless ECONOMETRICS 44-47 (2008).

66 See supra notes 42-43 and accompanying text.

67 Cf. Cynthia Estlund, What Should We Do After Work? Automation and Employment Law, 128 YALE L.J. 254, 258 (2018) (discussing claims that automation boosts profits while reducing the number of "midlevel jobs").

68 To reduce the problem of unobserved variable bias, some studies use panel data (meaning datasets containing observations for the same set of firms at different points in time). See, e.g., Bermig, supra note 63. Panel data have the advantage of allowing the use of firm fixed effects, meaning that one can compare a company's performance at a given time to that same 


\section{B. Difference-in-Differences}

One common econometric approach to overcome the limitation of correlation studies is to identify a so-called natural experiment, meaning some exogenous event, and apply a difference-in-differences analysis. 69 The intuition behind a difference-in-differences approach is straightforward. One identifies a group of subjects that the event impacts, the "treatment group," and another group that the event does not impact, the "control group." By comparing outcomes in the two groups before and after the fact, one can ascertain the event's impact.

Several well-known studies on codetermination employ this technique, typically using the enactment of the 1976 Codetermination Act as the treatment event.70 But these

company's average performance. This approach makes it possible to filter out the impact of time-invariant firm-level variables, even if one cannot observe these variables. For example, if a company's ownership structure does not change over time, then that ownership structure cannot be the reason why the company performs better in one year than in others. However, the use of firm fixed effects cannot exclude omitted variable bias resulting from variables that change over time. Furthermore, there may be many unobserved changes in a firm's economic, legal, and institutional environment that both impact a firm's performance and cause a firm to fall above or below the 2,000-employee threshold. Accordingly, even if regressions control for firm fixed effects, observed correlations can tell us very little about the impact of codetermination.

69 For a relatively recent analysis of the strengths and weaknesses of difference-in-differences approaches see, e.g., generally Michael Lechner, The Estimation of Causal Effects by Difference-in-Difference Methods, 4 Founds. \& TREnds Econometrics 165 (2011).

70 See, e.g., Felix R. FitzRoy \& Kornelius Kraft, Economic Effects of Codetermination, 95 SCANDINAVIAN J. ECON. 365, 366, 373 (1993) (using a sample of 112 German corporations, comparing their performance in 1975 and in 1983, and finding that parity codetermination is associated with lower productivity than on-third codetermination) [hereinafter FitzRoy \& Kraft, Economic Effects]; Frank A. Schmid \& Frank Seger, Arbeitnehmermitbestimmung, Allokation von Entscheidungsrechten und Shareholder Value [Codetermination, Allocation of Decision Rights, and Shareholder Value], 68 ZEITSCHRIFT FÜR BETRIEBSWIRTSCHAFT 453 (1998) (using a sample consisting of data for 160 publicly traded corporations in the years 1976, 1987, and 1991 and focusing on firms' market-to-book values as dependent variables); Kornelius Kraft \& Marija Ugarković, Gesetzliche 
studies yield contrary results: finding sometimes a negative impact on productivity, sometimes a positive impact, and sometimes no impact at all.71 Similarly, studies have yielded mixed results on whether or not the enactment of the 1976 Act led to higher wages. 72

This variation in findings is not particularly surprising if one takes into account the limitations of difference-indifferences studies. Such studies may be much more useful than mere correlation studies. Difference-in-differences designs are, in principle, a recognized "identification strategy," meaning an approach that uses observational

Mitbestimmung und Kapitalrendite [Codetermination and Return on Equity], 226 JAHRBÜCHER FÜR NATIONALÖKONOMIE UND STATISTIK 588 (2006) (using a sample of 179 firms for the years 1971 to 1976 and 1981 to 1986 and finding a small but statistically significant positive correlation between parity codetermination and return on equity); Michael A. Gurdon \& Anoop Rai, Codetermination and Enterprise Performance: Empirical Evidence from West Germany, 42 J. Econ. \& Bus. 289, 299 \& tbl.6 (1990) (using a sample of 63 firms and observations for the years 1970, 1975, 1980, and 1985 and finding that parity-codetermination is associated with a statistically significant decline in productivity but also, in certain years, with a significant increase in profitability).

71 Compare FitzRoy \& Kraft, Economic Effects, supra note 70, at 366 (finding a decline in productivity), with Felix FitzRoy \& Kornelius Kraft, Co-Determination, Efficiency and Productivity, 43 BRIT. J. INDUS. RELS. 233, 242 (2005) (finding an increase in productivity), and Kornelius Kraft, Productivity and Distribution Effects of Codetermination in an Efficient Bargaining Model, 59 INT'L J. INDUS. ORG. 458, 475-76 (2018) [hereinafter Kraft, Productivity] (finding no impact on productivity). Other authors have focused on firms' market-to-book ratios as a matter of firm performance. See, e.g., Schmid \& Seger, supra note 70, at 453 (using a sample of 160 firms, and finding that the introduction of the 1976 Codetermination Act resulted in an $18 \%$ decline in market-to-book ratios for treatment group firms).

72 Cf. FitzRoy \& Kraft, Economic Effects, supra note 70, at 372, 374 (finding no statistically significant evidence that the enactment of the 1976 Codetermination Act impacted wages but noting that it may have increased job security); Kraft, Productivity, supra note 71, at 458 (finding that the 1976 Codetermination Act increased workers' bargaining power vis-à-vis employers). 
data 73 to approximate a scientific experiment. 74 However, they remain vulnerable to omitted variable bias. ${ }^{75}$ Any change in an unobserved-and therefore omitted-variable that coincides with the treatment event and has a different impact on the treatment group and the control group can give the false impression of a treatment effect. 76

This general weakness of difference-in-differences studies looms large in the context of codetermination. Firms that have enough employees to trigger the application of the 1976 Codetermination Act and are therefore part of the treatment group differ from firms in the control group, which by definition have fewer employees. As a result, any change in the institutional, legal, or economic environment that occurs between the first and the second dates of observation and influences large firms differently compared to small firms can be mistaken for a treatment effect. To name just one example, the year 1979 saw the beginning of the second oil crisis, triggered by the Iranian Revolution in 1979 and compounded by the war between Iran and Iraq that began in 1980. There

73 Observational data are data not obtained from an actual experiment. See JeFFrey M. WoOldRIDGE, InTRODUCTORY ECONOMETRICS 2 (5th ed. 2013).

74 See ANGRIST \& PischKe, supra note 65 , at 6.

75 See JefFrey M. Wooldridge, Econometric AnAlysis of Cross SECTION AND PANEL DATA 130 (1st ed. 2002) (noting that the treatment event must "not be systematically related to" unobserved variables that may affect the dependent variable). Another limitation is that difference-in-differences studies rely on the so-called parallel trend assumption, meaning that the treatment-group firms and the control-group firms must have developed in a parallel fashion prior to the treatment event. See Ashesh Rambachan \& Jonathan Roth, An Honest Approach to Parallel Trends 1 (Nov. 12, 2020) (unpublished manuscript),

https://scholar.harvard.edu/files/jroth/files/honestparalleltrends_main.pdf [https://perma.cc/GX3J-6FFW].

76 Cf. ANGRIST \& PischKe, supra note 65, at 182 (cautioning that the difference-in-differences approach assumes that any omitted variables are time-invariant and noting that "[f]or many causal questions, the notion that the most important omitted variables are time-invariant doesn't seem plausible"). 
is no reason to believe that the oil crisis impacted larger firms in the exact same way that it affected smaller firms. 77

An additional challenge arises for studies that use firms that are subject to one-third codetermination as the control group and firms that are subject to parity codetermination as the treatment group.78 At most, this design may yield information about how the impact of parity codetermination compares to the impact of one-third codetermination. By contrast, such a design provides no direct evidence on whether parity codetermination produces better (or worse) outcomes than no codetermination.

\section{Event Studies}

Event studies focusing on the stock market's short-term reaction to events of interest are the workhorse of empirical corporate finance.79 Like difference-in-differences studies, event studies require a treatment event, such as the enactment of new legislation. Ideally, that treatment event impacts some firms but not others, creating a treatment group and a control group. As noted above, the 1976 Codetermination Act fits this mold since it only applies to firms with more than 2,000 employees, 80 thereby leaving public firms with 2,000 or fewer employees as the control group.

An event study uses a certain period before an event-the "estimation window"-to predict firms' stock price returns during the "event window," which often includes the day of the event itself plus one or two days. By subtracting a firm's

77 See Chun-Li Tsai, How Do U.S. Stock Returns Respond Differently to Oil Price Shocks Pre-Crisis, Within the Financial Crisis, and Post-Crisis?, 50 ENERGY ECON. 47, 58 (2015) (finding differences in the effects of oil shocks on differently-sized American firms).

78 E.g., FitzRoy \& Kraft, Economic Effects, supra note 70, at 373.

79 See Scott E. Harrington \& David G. Shrider, All Events Induce Variance: Analyzing Abnormal Returns When Effects Vary Across Firms, 42 J. Fin. \& QuANTITATIVE ANALYSIS 229, 229 (2007) ("[T] he short-horizon event study remains a workhorse of empirical finance in general and corporate finance in particular.").

80 See supra notes 42-43 and accompanying text. 
predicted stock return from its actual stock return during the event window, one obtains-for each day in the event window-a firm's abnormal stock return. 81 If the treatment group firms experience significantly different abnormal returns than the control group firms do, then, in the absence of confounding factors, it stands to reason that this difference is due to the event.

Several studies have used the event study methodology to explore the impact of codetermination on shareholder wealth. ${ }^{82}$ In general, these studies have found no statistically significant results, 83 or they have found that introducing or extending parity codetermination is associated with statistically significant negative abnormal returns. 84

While event studies are generally suitable to identify the shareholder wealth effects of legislation, they cannot answer the question of whether codetermination constitutes an efficient choice for German, let alone U.S., corporate law. Part of the problem is that Germany's social, institutional, and

81 The sum of the abnormal stock returns calculated for the different days of the event window equals the "cumulative" abnormal return.

82 See, e.g., Stefan Petry, Mandatory Worker Representation on the Board and Its Effect on Shareholder Wealth, 47 FIn. MGMT 25 (2018); Theodor Baums \& Bernd Frick, Co-Determination in Germany: The Impact of Court Decisions on the Market Value of Firms, 1 Econ. Analysis 143 (1998).

83 See, e.g., Baums \& Frick, supra note 82, at 149 (describing their research design), 153 (noting that "an extension of co-determination rights went together with a slight, but statistically insignificant increase in abnormal returns, whereas a restriction went hand in hand with a decrease that also proved to be insignificant" and pointing out that "the development of abnormal returns is rather erratic and shows no discernable pattern."), 155 tab. 6 (summarizing stock price reactions to twenty-three court decisions between 1974 and 1995 which either expanded or limited codetermination but finding no statistically significant results).

84 Stefan Petry analyzes the stock market's reaction to various legislative milestones on the way to the enactment of the 1976 Codetermination Act. See generally Petry, supra note 82 . He finds an average aggregate response of $-1.5 \%$ in cumulative abnormal returns relative to firms in the control group. $I d$ at 6 . Other studies have come to similar conclusions. See id. 
legal landscape looks very different now than it did in 1976.85 The fact that the 1976 Act may have reduced shareholder wealth at the time of its enactment does not necessarily imply that enactment today would have the same effect. 86

More importantly, an essential limitation of event studies is that they only capture the impact on shareholder wealth, not the impact on workers, even though workers are the intended beneficiaries of codetermination. 87

Finally, event studies face the challenge that they can measure an event's impact only on existing publicly-traded firms, since it is only for these firms that one can ascertain a stock market reaction to the event. The stock market's reaction does not allow researchers to estimate an event's impact on privately-held firms or firms formed after the event. To use a simple example, imagine that a country imposes strict fuel standards for the first time. The associated legislation may be bad news for existing car manufacturers. Still, it may offer benefits to entrepreneurs forming electric car companies in response to the new law; event studies do not capture these benefits. It is conceivable that codetermination allowed some new firms to flourish and go public that might not otherwise have achieved the same degree of success.

85 For an excellent account of the legal and institutional changes that are most pertinent to corporate law, see generally Wolf-Georg Ringe, Changing Law and Ownership Patterns in Germany: Corporate Governance and the Erosion of Deutschland AG, 63 AM. J. COMPAR. L. 493 (2015).

86 The same problem arises for studies that focus on court decisions or legislative changes extending or restricting the scope of Germany's codetermination regime if the relevant events occurred decades ago. See, e.g., Baums \& Frick, supra note 82, at 149 (describing their research design which relies on stock price reactions to twenty-three court decisions between 1974 and 1995).

87 The term "event study" is used here to refer to studies that measure the stock market's reaction to certain events. The stock market's reaction captures investors' beliefs about how an event impacts the value of stock but not beliefs about impacts on constituencies other than stockholders except to the extent that these also affect the values of stocks. 


\section{Instrumental Variables}

Another strategy to identify the impact of codetermination is to use instrumental variables.88 Even though the explanatory variable of interest-e.g., codetermination-may be correlated with unobserved variables, we can sometimes find another variable - the instrumental variable-that is correlated with the explanatory variable of interest but not with other explanatory variables or with the unobserved variables. 89 If so, one can establish causation between the explanatory variable of interest (e.g., codetermination) and the outcome variable (e.g., firm performance) by demonstrating a correlation between the instrumental variable and the outcome variable. 90

The following example, taken from one of the leading treatises on econometrics, may illustrate this strategy: in the nineteenth century, a scientist named John Snow tested whether unclean water transmitted cholera.91 A naïve approach would have been to look for a correlation between unclean water consumption and infection with cholera.92 However, any such correlation could have been due to other factors since, in practice, the consumption of impure water correlated with poverty. 93 Fortunately, Snow noticed that different water companies served otherwise similar households, and one company supplied cleaner water than the other.94 Because the identity of the water company was correlated with the explanatory variable of interest-water quality-but not with other explanatory variables or with unobserved variables, Snow could use the identity of the water

88 For a brief explanation of instrumental variables see, e.g., WOOLDRIDGE, supra note 75, at 83-89.

89 See WoOLDRIDGE, supra note 73, at 84-85.

90 See ANGRIST \& PISCHKE, supra note 65, at 117 (discussing the possibility of causal inference).

91 William H. Greene, Econometric AnAlysis 252-54 (8th ed. 2018).

92 See id. at 252.

93 See id.

94 See id. 
company as an instrument to demonstrate that impure water was the cause of cholera infections. 95

To return to the issue of codetermination, recall that finding a correlation between codetermination and other variables of interest, such as firm productivity, does not tell us much since there may be unobserved variables that cause the firm to hire more employees and thereby trigger the application of parity codetermination while at the same time causing the firm to be more productive. 96

One could avoid these biases if it were possible, first, to find a purely exogenous variable that causes the 1976 Act to be applicable, provided that, second, the only way in which this exogenous variable can impact firm productivity is through the application of the Act. In that case, a correlation between the exogenous variable and firm performance would suggest that codetermination affects firm performance. However, to the best of our knowledge, no paper to date has identified an instrumental variable for codetermination that satisfies these twin challenges. For example, one paper uses various firm characteristics to predict the number of a firm's employees and then uses that predicted value as an instrument for the applicability of codetermination. 97 But the problem with this approach is that the firm characteristics used to predict the number of employees may well have an impact on firm performance, implying that the instrument may impact the outcome of interest through channels other

95 See id. at $253-54$.

96 See supra text accompanying notes $65-68$. It is even conceivable that firm productivity (indirectly) causes the application of the 1976 Codetermination Act rather than the reverse.

97 Fauver and Fuerst have taken this approach to estimate the impact of codetermination on various variables of interest, most notably firm performance, as measured by Tobin's q. Fauver \& Fuerst, supra note 63, at 704 app., tbl.A.1. They proceed as follows: in a first step, they use several firm characteristics such as a firm's industry to predict the number of a firm's employees. See id. In a second step, they use this predicted value as an instrument for the level of codetermination and find a positive correlation with Tobin's q. See id. 
than codetermination. 98 For example, many factors, such as a firm's industry, influence the number of employees and thereby, indirectly, the level of codetermination. However, a firm's industry also impacts a firm's performance regardless of the applicable codetermination regime. 99

To conclude, decades of empirical research on codetermination lead to a sobering assessment: the results hardly yield a compelling case for or against the policy. 100 As a consequence, the case for and against codetermination cannot be made simply by pointing to hard empirical evidence. Moreover, empirical studies with data from Germany or other European countries inevitably raise the question of external validity:101 given different social, regulatory, and institutional environments, one cannot easily assume the results of the relevant studies can be extrapolated to the United States. Qualitative arguments that go beyond what is easily measurable are necessary.

98 In more technical terms, the instrument (predicted number of employees) may be correlated with the error term.

99 For example, Fauver \& Fuerst, supra note 63, at 704 app., tbl.A.1., use Tobin's q to measure firm performance. However, for reasons that have nothing to do with codetermination, Tobin's q correlates with industry. See, e.g., Dong Lee, Hyun-Han Shin \& René M. Stulz, Does Capital Flow More to High Tobin's Q Industries? 10 (Fisher Coll. of Bus. Working Paper No. 03-008, 2018) ("[T] he average difference in median Tobin's q between high funded and low-funded industries is 0.184 and [is] statistically significant at the $1 \%$ level."). The correlation between industry and Tobin's q is unsurprising given that Tobin's q, to a large extent, measures a firm's growth opportunities. See id. at 1.

100 A more recent study, Simon Jäger, Benjamin Schoefer \& Joerg Heining, Labor in the Boardroom 19 (Oct. 20, 2020) (unpublished manuscript), http://economics.mit.edu/files/17273 [https://perma.cc/SJE92T23], makes use of a so-called regression-discontinuity approach. However, that the study finds no effect of moving from one-third codetermination to parity-codetermination for wages and wage structures. See id. at 33. The study also fails to find any negative profitability impact of codetermination, though the authors caution that this may be due to data limitations. See id. For a simple introduction to regression discontinuity, see ANGRIST \& PISCHKE, supra note 65, at 189-201.

101 The term "external validity" refers to the "predictive value of [a] study's findings in a different context." ANGRIST \& PISCHKE, supra note 65, at 111 . 


\section{THE BENEFITS OF CODETERMINATION}

Despite the inconclusive empirical cases for and against codetermination, it is plausible that codetermination has allowed Germany to reap important monetary or nonmonetary benefits. However, as this Part shows, in the United States, similar benefits are unlikely to materialize. As a consequence, focusing on the benefits of codetermination alone, the case for introducing codetermination in the United States is weaker than it was in Germany. And it is even weaker when considering, as Part VI does, the costs of codetermination.

\section{A. Collective Bargaining}

Henry Hansmann has argued that codetermination may yield important efficiency benefits in the context of collective bargaining. 102 Corporate boards typically know more about their companies' financial situations than the labor unions with whom they bargain.103 This informational asymmetry may prevent the bargaining parties from reaching an agreement, because unions may suspect that employers describe their firms' financial prospects negatively in order to obtain lower wages. Meanwhile, employers may be unable to demonstrate their honesty in a credible way. Strikes, which can be costly both for the parties involved and for other companies up or down the supply chain, may be the consequence. ${ }^{104}$ Codetermination, however, ensures that the employee representatives have access to the same information

102 See Henry Hansmann, When Does Worker Ownership Work? ESOPs, Law Firms, Codetermination, and Economic Democracy, 99 YALE L.J. 1749, 1803 (1990).

103 See id. ("[C]odetermination ... gives workers ... accurate and credible information about the firm that would otherwise be confined to management.").

104 See id. at 1766 (explaining that information asymmetries between management and labor "increase the incentive for both labor and management to adopt bargaining strategies, such as strikes and lockouts, that significantly raise the transaction costs of reaching agreement"). 
as other board members. 105 As a result, mandatory codetermination can mitigate or eliminate the information asymmetry between employers and workers. 106

However, the magnitude of this benefit depends on the role that collective bargaining plays in a country's economy. 107 In the United States, this role is far smaller than it is in Germany and other European countries. 108 As Table 3 shows, in 2015, the most recent year for which coverage rates are available for both the United States and Germany, collective bargaining agreements covered only $7.2 \%$ of private-sector employees in the United States. In contrast, the coverage rate for private-sector employees in Germany was 50.2\%. Other European countries that provide for mandatory employee representation on corporate boards such as Austria, France, Norway, and Sweden also tend to have much higher coverage rates than the United States. Meanwhile, the United Kingdom, where collective bargaining agreements cover relatively few private-sector workers, requires no form of employee representation on corporate boards. 109

$105 C f$. Bundesgerichtshof [BGH] [Federal Court of Justice] Feb. 25, 1982, Neue JURISTISCHE Wochenschrift [NJW] 1530, 1530-31 (Ger.) (holding that employee representatives and shareholder representatives must be treated equally).

106 The role of codetermination in reducing asymmetric information in the context of collective bargaining is now widely accepted. See, e.g., Luca Enriques et al., The Basic Governance Structure: Minority Shareholders and Non-Shareholder Constituencies, in The Anatomy of Corporate LaW 79, 105 (3rd ed. 2017); Jens Dammann, The Mandatory Law Puzzle: Redefining American Exceptionalism in Corporate Law, 65 Hastings L.J. 441, 479 (2014).

107 To some extent, employees bargaining individually with their company might also benefit from better information. However, even if one assumes that an individual employee has enough leverage to negotiate their salary and that the employer's economic prospects play a central role in this negotiation, an individual employee's bargaining generally will prove less disruptive to the company than collective strikes.

108 See Dammann, supra note 106, at 480-81.

109 Then-Prime Minister Theresa May considered reforms between 2016 and 2018, but her proposals stalled. See Larry Elliott, Theresa May Misses a Trick After U-Turn on Workers on Boards, GUARDIAN (June 10, 2018, 6:57 PM), 
Table 3. Percentage of Private Sector Employees Covered by Collective Bargaining Agreements

\begin{tabular}{llllll}
\hline & Austria & Belgium & France & Denmark & Germany \\
\hline 2017 & $94.0 \%$ & N.A. & N.A. & N.A. & N.A. \\
2016 & N.A. & $90.0 \%$ & N.A. & $74.0 \%$ & N.A. \\
2015 & N.A. & N.A. & $90.2 \%$ & N.A. & $51.2 \%$ \\
\hline & Norway & Spain & Sweden & U.K. & U.S. \\
\hline 2017 & $52.0 \%$ & $59.0 \%$ & N.A. & $15.2 \%$ & $7.3 \%$ \\
2016 & $54.0 \%$ & $62.8 \%$ & $85.0 \%$ & $14.9 \%$ & $7.3 \%$ \\
2015 & N.A. & $61.2 \%$ & $84.0 \%$ & $14.7 \%$ & $7.4 \%$ \\
\hline
\end{tabular}

Note: All data are from Version 6.1 of the Data Base on Insitutional Characteristics of Trade Unions, Wage Setting, State Intervention and Social Pacts. See Jelle Visser, ICTWSS Downloads, AIAS: ICTWSS (last updated Nov. 2019),

https://www.ictwss.org/downloads [https://perma.cc/UTV7-FQSV].

Of course, even the United States might benefit from the disclosure function of codetermination law, at least to some extent. However, given the low percentage of private-sector workers covered by collective bargaining agreements, it stands to reason that the relevant benefits would be relatively limited.

\section{B. Firm-Specific Investments}

Scholars have argued that codetermination may encourage employees to make firm-specific investments. 110 The basic idea is simple: firms often can increase their productivity by persuading employees to acquire knowledge or skills that are useful as long as the employee works for that particular company but have little value anywhere else. ${ }^{111}$ For example,

https://www.theguardian.com/business/2018/jun/10/theresa-may-misses-atrick-after-u-turn-over-workers-on-boards [https://perma.cc/A9QR-7PKJ].

110 See, e.g., Eirik G. Furubotn, Codetermination and the Modern Theory of the Firm: A Property-Rights Analysis, 61 J. Bus. 165, 174 (1988).

111 See id. at 168 ("[L]abor's investment in the firm can be understood as a vital input; the capital in question represents nothing less than one part of the total capital stock needed by the firm for production."). 
a corporation benefits if an engineer becomes acquainted with the corporation's particular manufacturing processes and patents, even though the engineer may not be able or allowed to use that knowledge in subsequent positions at other firms.

From an employee's perspective, firm-specific investments are risky. After all, the employer knows that the employee cannot take his firm-specific expertise elsewhere.112 As a result, the employer may encourage employees to make firmspecific investments but then refuse to compensate them for their increased productivity. ${ }^{113}$ The prospect of employer opportunism may lead the employee to abstain from making firm-specific investments in the first place, even where such investments would produce positive joint payoffs for the parties. Codetermination, the argument runs, is a mechanism that allows employers to make a credible commitment to reward employees for their firm-specific investments. 114 Given employee representation on the board, employees could anticipate fair treatment and that firm-specific investments would pay off.

Part of the problem with this theory is that there is no empirical evidence to back it up. We are not aware of any study showing that codetermination makes employees more willing to make firm-specific investments. Furthermore, it is worth noting that Germany has adopted many different rules that protect employees against ex post expropriation by employers and encourage firm-specific investments. For example, whereas U.S. firms can generally fire employees at

112 See id. at 167 (noting that employees typically cannot move between employers without nontrivial costs).

113 See id. ("[W]orker-investors, if unprotected by institutional or contractual safeguards, may be exploited and suffer serious economic injury.").

114 See E. Han Kim, Ernst Maug \& Christoph Schneider, Labor Representation in Governance as an Insurance Mechanism, 22 REV. FIN. 1251, 1256 (2018) ("Workers often have to . . . make investments in firmspecific human capital ...., which makes them vulnerable to breaches of implicit contracts.... [P] arity-codetermination serves as a commitment device by allowing workers to influence employment decisions." (citation omitted)). 
will,115 German employment law adheres to the for-cause termination rule, under which employers need a specified (personal or business) reason to end an employment relationship.116 Moreover, collective bargaining agreements aimed at ensuring fair wages cover many German workers. 117

Additionally, German labor law does not just give employees a voice in the supervisory board. It also requires "works councils" designed to safeguard the rights of employees. Employees in companies with five or more employees have the right to elect a works council,118 and employers must either inform the works council or seek its approval on many important managerial issues. 119 In their entirety, these rules offer a high level of protection to German employees, and it shows. For instance, for male workers between the ages of eighteen and sixty, the average job tenure is about four years in the United States versus seven years in Germany. ${ }^{120}$

Adopting a German-style system of codetermination may be one step towards encouraging more firm-specific investment. However, it is not clear that mandatory

115 See Julie C. Suk, Discrimination at Will: Job Security Protections and Equal Employment Opportunity in Conflict, 60 STAN. L. REV. 73, 78-79 (2007).

116 See Kündigungsschutzgesetz [KSchG] [Dismissal Protection Act], Aug. 25, 1969, BGBL I at 1317, § 1, last amended by Gesetz [G], July 17, 2017, BGBL I at 2509, art. 4 (Ger.).

117 See supra Section V.A tbl.3.

118 Betriebsverfassungsgesetz [BetrVG] [Works Constitution Act], Oct. 11, 1952, BGBL I at 681, revised Jan. 15, 1972, BGBL I at $13 \S 1(1)$, last amended by Gesetz [G], May 20, 2020, BGBL I at 1044, art. 6 (Ger.). Note, though, that the obligation to create a works council arises only if at least five of the company's employees are at least 18 years old. See id. $\S 7(1)$ (providing that employees have the right to vote in works council elections if they are at least 18 years old). Furthermore, at least three of the five employees must meet eligibility requirements, $i d$. $\S 1(1)$, which generally requires that they have worked for the employer for at least six months. See id. $\S 8(1)$.

119 See id. $\S \S 81,90$ (listing matters requiring notice); see also id. $\S \S 87$, 91 (listing matters in which the works council has a co-decision right).

120 Kenneth A. Couch, Tenure, Turnover, and Earnings Profiles in Germany and the United States, 1 J. Bus. \& Econ. Rsch. 1, 3 (2011). 
codetermination is an important, or even the most important, factor to achieve this end. And there is no evidence at all that adopting mandatory codetermination in isolation will make much of a difference.

\section{Employee Interests}

Codetermination on corporate boards may also have benefits that are hard to quantify. Employees could derive satisfaction from having a say in how a company operates or from feeling at least partly in control of their own fates.121 Even though such benefits are hard to quantify, a complete cost-benefit analysis should consider them.

At first glance, benefits of this type should be universal in character and should not depend significantly on the institutional fabric of a specific jurisdiction. We do not attempt to verify or falsify this claim. Instead, we argue that, whatever intangible benefits employees derive from a codetermination regime, it is probably small or even immaterial compared to the interests of employees in secure and well-paying jobs.

When the discussion on board codetermination took shape in post-war Germany in the late 1940s, "[t]he prevailing view at the time was that political democracy must be combined with social constraints over the use of private capital, a concept that has been termed 'economic democracy' (Wirtschaftsdemokratie)."122 Potential benefits of codetermination included a "democratization" of political and business life going much beyond corporate governance-related improvements.

121 Hansmann, supra note 102, at 1769-70 (pointing out that "individual workers might enjoy the process of collective decision-making as a communal activity that is satisfying in itself quite apart from the character of the decisions reached," but also noting that the distribution of employee-owned firms, which tend to arise in industries "where firms are relatively small and have relatively homogeneous work forces with little hierarchy" suggests that alienation may not be an important factor).

122 Katharina Pistor, Codetermination: A Sociopolitical Model with Governance Externalities, in EMPLOYEES AND CORPORATE GOVERNANCE 163, 167 (Margaret M. Blair \& Mark J. Roe eds., 1999). 
One aspect of this goal related to the protection of human dignity, a fundamental human right (and interest). Article 1(1) of the German Constitution (Grundgesetz) stipulates that "[h] uman dignity shall be inviolable."123 Scholars argued that board codetermination would protect employees from becoming mere objects of business decisions that they could not influence, let alone control.124 Furthermore, the proponents of codetermination argued that the 1976 Act would lead employees to engage more with the affairs of their firms and develop a sense of responsibility-traits that were said to strengthen democracy. ${ }^{125}$ The value employees placed on codetermination's protections could be inferred from such effects.

These are views on which reasonable minds can differ. Whatever the merits of the argument that, without codetermination, employees are mere objects of decisions taken by others, it seems clear to us that board codetermination would not address the main concern of employees working today.

We very much suspect their main concern is not being treated in a dehumanizing fashion at their workplace in a (large) corporation. Rather, it is losing their job entirely or having to move into the precarious position of a (seemingly) independent contractor in the gig economy. 126 This concern has become even more acute because of the COVID-19 pandemic. (Seemingly) independent contractors all over the world, including in the United States, are facing the economic abyss. Of course, the crisis affects corporations, too.127 But

123 Grundgesetz [GG] [Basic Law], translation at https://www.gesetzeim-internet.de/englisch_gg/ [https://perma.cc/53X6-WE6X].

124 See Thomas Raiser, Paritätische Mitbestimmung in einer freiheitlichen Wirtschaftsordnung [Parity Codetermination in a Free Market System], 29 JURISTENZEITUNG [JZ] 273, 276 (1974).

125 See id.

126 For a balanced account of this development, see generally JEREMIAS Prassl, Humans as a Service: The Promise and Perils of Work in the Gig ECONOMY (2018).

127 See Patrick Mathurin, Ortenca Aliaj \& James Fontanella-Khan, Pandemic Triggers Wave of Billion-Dollar U.S. Bankruptcies, FIN. TIMES (Aug. 21, 2020), https:/www.ft.com/content/277dc354-a870-4160-9117- 
large corporations operate as a kind of firewall between the crisis and the individual worker: wages are somewhat "sticky" during bad economic times, meaning that even as employment falls, employers tend to abstain from lowering wages. 128

The underlying logic is well-recognized in labor economics. Assuming that firms are risk-neutral but employees generally are risk-averse, it makes economic sense to shift the risk of labor market fluctuations from employees to the corporation. 129 Under this model, a firm and its employees enter into an implicit contract, under which employees accept lower wages in exchange for the implicit promise that the firm will refrain from lowering his or her wages during bad times. 130 Empirical evidence from labor markets is consistent with this model. 131

Independent contractors do not have the benefit of this buffer. In addition, empirical research has demonstrated that employees in large corporations receive better pay than those

b5b0dece5360 (on file with the Columbia Business Law Review) (reporting that as of August 17, 2020, forty-five companies with assets in excess of $\$ 1$ billion filed for bankruptcy under Chapter 11 compared to eighteen such companies during the same period in 2019 and thirty-eight during the same period in 2009).

128 See Ernst Fehr \& Armin Falk, Wage Rigidity in a Competitive Incomplete Contract Market, 107 J. PoL. ECON. 106, 107 (1999) ("Recently performed questionnaire studies with owners and managers of firms suggest that employers are unwilling to cut wages in the presence of unemployment."); Robert E. Hall, Employment Fluctuations and Wage Rigidity, 1980 Brookings Papers ECON. ACTIVITy 91, 91 (1980) ("During the past decade, two facts about the U.S. labor market became more apparent than ever before: the large magnitude of fluctuations in employment and the lack of any strong response of wages to these fluctuations.").

129 See Oliver D. Hart, Optimal Labour Contracts Under Asymmetric Information: An Introduction, 50 REV. ECON. STUD. 3, 3 (1983); Edward N. Gamber, Long-Term Risk-Sharing Wage Contracts in an Economy Subject to Permanent and Temporary Shocks, 6 J. LAB. ECON. 83, 83-84 (1988).

130 See Gamber, supra note 129 , at 84.

131 See id. at 96-97 (providing empirical evidence that wages respond more strongly to permanent then to temporary shocks, which is consistent with an income smoothing function for employment). 
working in small and midsize enterprises, 132 although that difference has been shrinking somewhat in recent years. 133 Against this background, advocating board codetermination in large corporations on the basis that it would help humanize and "dignify" workplace conditions in such corporations is beside the point.

\section{THE COSTS OF CODETERMINATION}

Codetermination has costs as well as benefits. These costs are bound to arise in any country that adopts mandatory codetermination. However, as shown below, they are likely to be much greater in the United States than they are in Germany. As a consequence, and taking into account that any benefits of codetermination would be significantly smaller in the United States than in Germany, the economic case for introducing mandatory codetermination in the United States is extremely weak.

\section{A. The Functioning of the Board}

One of the core challenges of mandatory codetermination is that it guarantees divided loyalties within the board: the shareholder representatives know that they must please the shareholders to get reelected, whereas the worker representatives know that their reelection depends on keeping employees satisfied.134 These different perspectives

132 See Christoph M. Schmidt \& Klaus F. Zimmermann, Note, Work Characteristics, Firm Size, and Wages, 73 Rev. Econ \& STATS. 705, 705 (1991) (noting that larger firms pay higher wages than smaller firms); Nicholas Bloom et al., The Disappearing Large-Firm Wage Premium, 108 AEA PAPERS \& PROC. 317, 317 (2018) ("Large firms pay higher wages than smaller firms even after controlling for the quality of a worker.”).

133 Bloom et al., supra note 132, at 317 (finding that the average wage premium that workers in firms with at least 10,000 employees earn compared to firms with 100 or fewer employees has declined from $47 \%$ in the early 1980 s to $20 \%$ by the early 2010 s).

134 See Klaus J. Hopt, supra note 62, at 206 ("[T] he conflict of interests problem is considered to be serious. ... It is clear that the expectations of the workers and the unions set into 'their' representatives are irreconcilable with . . a neutral role.”). 
can make it harder for boards to work constructively towards the same end. 135

Of course, there now exists a rich literature emphasizing the benefits of diverse boards. In particular, having directors with different experiences and viewpoints can, in principle, avoid problems like groupthink and thereby improve decisionmaking. ${ }^{136}$ Against this background, skeptics may be tempted to dismiss our reasoning by arguing that it ignores the benefits of viewpoint diversity. However, this objection would misunderstand our argument. We do not question the value of board diversity. Instead, we would like to point out that corporations can reap the benefits of diversity without the downside of having directors with fundamentally different goals. 137

135 Cf. Mark J. Roe, German Codetermination and German Securities Markets, 1998 Colum. Bus. L. REV. 167, 168 (noting that "low conflicts of interest" are one of the factors that make boards effective). In fact, because workers often have very heterogenous interests depending on their jobs, ages, seniorities, and salaries, conflicts of interests among board members often would be substantial even if the board consisted solely of employee representatives. $C f$. Henry HANSMANn, THE OWNERShIP OF ENTERPRISE 8991 (1996) (explaining that different groups of employees have different interests and that these different interests substantially increase the costs of collective decisionmaking).

136 See, e.g., Douglas M. Branson, No Seat at the Table: How Corporate Governance and LaW Keep Women Out of the BoARdroom 177-78 (2007); Seletha R. Butler, All on Board! Strategies for Constructing Diverse Boards of Directors, 7 VA. L. \& Bus. REV. 61, 76 (2012); Lynne L. Dallas, Short-Termism, the Financial Crisis, and Corporate Governance, 37 J. CoRP. L. 265, 276 (2012).

137 To the extent that corporations fail to diversify their boards voluntarily, states can adopt legislation imposing gender or ethnic quotas for corporate boards. California has adopted both types of quotas. California's gender quota can be found in CAL. CORP. CODE $\S 301.3$ (West 2020). Senate Bill 826 added the original version of this provision to the California Code and became effective in 2019. See S.B. 826, 2017-2018 Leg., Reg. Sess. (Cal. 2018). By the end of 2021, a public corporation whose principal executive office is located in California, must have at least three female directors if the total number of directors is six or more. CAL. CORP. CODE $\S 301.3(\mathrm{~b})$. If the total number of directors is five, the corporation must have at least two female directors, and if the total number of directors is less than five, the corporation must have at least one female director. Id. 
The beneficiaries of a less functional board might be a corporation's managers. If employee representatives and shareholder representatives on the board cannot agree on goals, strategies, or supervisory measures, managers are likely to gain more leeway in pursuing self-interested actions to the detriment of both shareholders and employees. Agency costs in the form of managerial opportunism are the probable result. 138 For example, as the intensity with which boards monitor managers declines, managers may exploit their discretion to shirk or to waste corporate resources on unprofitable "pet projects" 139 or "empire-building." 140

The rise and fall of cumulative voting illustrates the importance of board collegiality. 141 Cumulative voting can help minority shareholders elect some of their representatives to the board.142 Despite the potential salutary effect of

California's quota for underrepresented communities can now be found in CAL. CORP. CODE $§ 301.4$. By the end of 2022, a public corporation whose principal executive office is located in California, must have at least three directors from underrepresented communities if the total number of directors is nine or more. CAL. CORP. CODE $§ 301.4(\mathrm{~b})$. The corporation must have at least two directors from underrepresented communities if the total number of directors is at least five but less than nine, and the corporation must have at least one director from an underrepresented community if the total number of directors is four or fewer. $I d$. A 2020 bill added introduced this rule. See A.B. 979, 2019-2020 Leg., Reg. Sess. (Cal. 2020).

138 On the agency costs associated with the separation of ownership and control, see infra Section VI.B. On monitoring as the key function of the board, see Stephen M. BAinbridge \& M. Todd Henderson, Outsourcing THE BOARD 45-48 (2018).

139 See Simone M. Sepe, Intruders in the Boardroom: The Case of Constituency Directors, 91 WASH. U. L. REV. 309, 319 (2013).

140 See Edward B. Rock, Adapting to the New Shareholder-Centric Reality, 161 U. PA. L. REV. 1907, 1915 (2013).

141 Cumulative voting enjoyed such recognition that many states made cumulative voting mandatory. See Jeffrey N. Gordon, Institutions as Relational Investors: A New Look at Cumulative Voting, 94 Colum. L. REV. 124, 145 (1994) (noting that in the 1940s, no fewer than twenty-two states had mandatory rules requiring cumulative voting in corporate elections).

142 See John F. Coyle, Altering Rules, Cumulative Voting, and Venture Capital, 2016 UTAH L. REV. 595, 597-98. 
minority shareholder representation on monitoring, 143 and even though minority and majority shareholders typically share the basic goal of maximizing shareholder wealth, 144 practitioners viewed the resulting board composition as so detrimental to collegiality 145 that state lawmakers and corporate charters have largely turned their backs on it.146 This modern practice finds support in more recent empirical studies, which provide evidence that cumulative voting reduces firm value.147 Cumulative voting rules are very different from codetermination. However, the lesson from cumulative voting is that board collegiality needs to be taken seriously when considering codetermination's potential costs.

143 For an endorsement of cumulative voting, see Gordon, supra note 141 , at 127.

144 See Frank H. Easterbrook \& Daniel R. Fischel, The Economic STRUCTURE OF CORPORATE LAW 70 (1991) (noting that shareholders have relatively homogenous interests in maximizing shareholder wealth); HANSMANN, supra note 135 , at 62 ("[S]hareholders share a single welldefined objective: to maximize the net present value of the firm's earnings.").

145 See, e.g., Charles W. Steadman \& George D. Gibson, Should Cumulative Voting for Directors Be Mandatory?-A Debate, 11 Bus. LaW. 9, 26-29 (1955).

146 See Gordon, supra note 141, at 189 app. 2. However, some states still permit cumulative voting. See, e.g., CAL. CoRP. CoDE $\S \S 301.5,708($ a) (West 2020) (mandating cumulative voting for unlisted corporations, while allowing listed corporations to opt out in their articles of incorporation or bylaws).

147 See Stuart L. Gillan \& Laura T. Starks, Corporate Governance Proposals and Shareholder Activism: The Role of Institutional Investors, 57 J. FIN. ECON. 275, 299-300 (2000) (finding that the rejection of shareholder proposals for cumulative voting was associated with statistically significant positive abnormal returns); James Nelson, Corporate Governance Practices, CEO Characteristics and Firm Performance, 11 J. CORP. Fin. 197, 220-21 (2005) (finding that a firm's decision to abolish cumulative voting was associated with positive long-term abnormal returns, whereas the decision to adopt cumulative voting was associated with negative long-term abnormal returns). But see Sanjai Bhagat \& James A. Brickley, Cumulative Voting: The Value of Minority Shareholder Voting Rights, 27 J.L. \& Econ. 339, 353, 354 tbl.2, 355 (1984) (finding that charter amendments eliminating cumulative voting were associated with negative abnormal returns). 
Of course, the problem that mandatory codetermination may undermine board collegiality is not limited to the United States. It exists in Germany, as well.148 But German corporate law provides for a two-tier board structure and charges the managing board, rather than the supervisory board, with the day-to-day management of the company.149 In addition, unlike the supervisory board, the managing board is not subject to mandatory codetermination requirements. 150 Perhaps for this reason employee and shareholder directors often work together relatively smoothly. 151

\section{B. Removal of Directors}

One of the most obvious problems in corporate law is the agency conflict between directors and the corporation. Directors are fiduciaries who are supposed to act in the best interest of the corporation. 152 Traditionally, that has meant that directors are supposed to act in the best interest of shareholders. 153 In a stakeholder model, it means that directors must act in the best interests of multiple

148 In practice, problems appear to arise in particular with those employee directors who represent the trade unions. See Klaus J. Hopt, The German Two-Tier Board: Experience, Theories, Reforms, in CoMPARATIVE Corporate Governance: The State of the ART AND EMERGING REsEARCH 227, 235 (Klaus J. Hopt et al. eds., 1998) (noting that employee directors representing trade unions "are considered to be outsiders in the enterprise and behave as such, making consensus more difficult").

149 Aktiengesetz [AktG] [Stock Corporation Act], Sept. 6, 1965, BGBL I at $1089, \S 76(1)$, last amended by Gesetz [G], July 17, 2017, BGBL I at 2446, art. 9 (Ger.).

$150 C f$. Gesetz über die Mitbestimmung der Arbeitnehmer [MitbestG] [Codetermination Act], May 4, 1976, BGBL I at 1153, § 7(1), last amended by Gesetz [G], Apr. 24, 2015, BGBL I at 642, art. 7 (Ger.).

151 See John W. Cioffi, Review Essay, State of the Art: A Review Essay on Comparative Corporate Governance: The State of the Art and Emerging Research, 48 AM. J. COMPAR. L. 501, 526-27 (2000) (“[O]ne sees surprisingly little conflict between managers and shareholders and employees in German corporate governance.").

152 See, e.g., N. Am. Cath. Educ. Programming Found., Inc. v. Gheewalla, 930 A.2d 92, 101 (Del. 2007).

153 See id.; Allen v. El Paso Pipeline GP Co., 113 A.3d 167, 180 (Del. Ch. 2014). 
constituencies. 154 In either case the problem is the same: directors may be tempted to put their own interests ahead of those that they are meant to serve. For example, directors may use their influence to obtain excessive salaries, 155 to engage in empire-building, 156 or to entrench themselves in office, 157 thereby preventing the corporation from getting better managers.

Corporate law and private ordering offer various ways in which corporations can minimize agency costs. These include performance-based compensation, 158 an active market for corporate control, 159 and active monitoring by institutional investors.160 Shareholders can also discipline directors

154 For example, Senator Warren's Accountable Capitalism Act defines directors' duties in this way. See Accountable Capitalism Act, S. 3348, 115th Cong. § 5(c)(1) (2018) (requiring directors to "balance[] the pecuniary interests of the shareholders . . . with the best interests of persons that are materially affected by the conduct of the . . corporation").

155 See Zohar Goshen \& Gideon Parchomovsky, The Essential Role of Securities Regulation, 55 DUKE L.J. 711, 749 (2006). For a thorough analysis of the problem of excessive CEO compensation, see generally LUCIAN Bebchuck \& Jesse Fried, Pay Without Performance: The Unfulfilled Promise of Executive Compensation (2004).

156 See Oliver Hart \& John Moore, Debt and Seniority: An Analysis of the Role of Hard Claims in Constraining Management, 85 AM. ECON. REV. 567, 568-69 (1995).

157 See Robert K. Rasmussen, The Ex Ante Effects of Bankruptcy Reform on Investment Incentives, 72 WASH. U. L.Q. 1159, 1176 (1994).

158 See Gregg D. Polsky, Controlling Executive Compensation Through the Tax Code, 64 WASH. \& LEE L. REV. 877, 890 (2007); George G. Triantis, Slack Policy and the Laws of Secured Transactions, 29 J. LEGAL STUD. 35, 39 (2000).

159 See Michael C. Jensen, The Modern Industrial Revolution, Exit, and the Failure of Internal Control Systems, 48 J. Fin. 831, 850-52 (1993); Jonathan Klick \& Robert H. Sitkoff, Agency Costs, Charitable Trusts, and Corporate Control: Evidence from Hershey's Kiss-Off, 108 Colum. L. REV. 749, 788 (2008); Triantis, supra note 158, at 39.

160 See Bernard S. Black, Agents Watching Agents: The Promise of Institutional Investor Voice, 39 UCLA L. REV. 811, 813-14 (1992); Ronald J. Gilson \& Jeffrey N. Gordon, Controlling Controlling Shareholders, 152 U. PA. L. REV. 785, 785 (2003). 
through the threat of removal.161 Admittedly, Delaware law allows corporations to blunt that threat by classifying ("staggering") boards. On a classified board, shareholders can remove directors only for cause, 162 and among publicly-traded corporations, classified boards used to be the rule rather than the exception. 163 Recently, however, shareholders have pushed back against the proliferation of classified boards. As Marcel Kahan and Ed Rock have shown, between 2003 and 2009 the percentage of S\&P 100 corporations with classified boards declined from forty-four percent to sixteen percent. 164 There are good reasons why shareholders dislike classified boards. A substantial number of empirical studies have examined the impact of classified boards and found that they tend to reduce firm value. 165

Against this background, the question arises whether codetermination facilitates the removal of directors or makes it more difficult. Germany's 1976 Codetermination Act allows for the removal of employee representatives on the supervisory board but requires a three-fourths majority of the

161 See Julian Velasco, The Fundamental Rights of the Shareholder, 40 U.C. DAVIS L. REV. 407, 451 (2006) ("Ultimately, what prevents directors from ignoring shareholders is the threat of removal.").

162 DeL. CoDE ANN. tit. 8, § 141(k)(1) (2020).

163 See Michael Klausner, Fact and Fiction in Corporate Law and Governance, 65 StAN. L. REV. 1325, 1335 (2013).

164 Marcel Kahan \& Edward Rock, Embattled CEOs, 88 Tex. L. REv. 987, 1008 tbl.2, 1009 (2010).

165 See, e.g., Lucian A. Bebchuk \& Alma Cohen, The Costs of Entrenched Boards, 78 J. Fin. ECON. 409, 430 (2005) (concluding that staggered boards are associated with a lower Tobin's q); Alma Cohen \& Charles C.Y. Wang, How Do Staggered Boards Affect Shareholder Value? Evidence from a Natural Experiment, 110 J. Fin. ECON. 627, 640-41 (2013) (finding that staggered boards reduce firm value); but see Yakov Amihud \& Stoyan Stoyanov, Do Staggered Boards Harm Shareholders?, 123 J. FIN. ECON. 432, 438 (2017) (examining Cohen \& Wang, supra, and claiming that their results become statistically insignificant once one includes proper controls). For a rebuttal of this critique, see generally Alma Cohen \& Charles C.Y. Wang, Reexamining Staggered Boards and Shareholder Value, 125 J. Fin. ECON. 637 (2017). 
employees to vote in favor of removal.166 However, the difficulty of removing an incompetent board member may not be excessively harmful because the supervisory board is not entrusted with the day-to-day management of the corporation.

Neither Sanders's nor Warren's proposal mentions the removal of employee representatives, 167 but any procedure allowing for removal will be clumsy. The decision must be left to the employees, or else their right to elect representatives would be undermined. But employees would face the same collective action problem that shareholders do when it comes to informed voting. Crucially, while the existence of institutional investors greatly reduces the collective action problem for shareholders, 168 this solution is unavailable to employees, assuming that if the United States were to introduce codetermination, each shareholder would only be given one vote.

In sum, it seems likely that mandatory codetermination would make the removal of employee directors very difficult, and because of America's single-tier board structure, this problem would be much more severe in the United States than it is in Germany.

\section{Bankruptcy Governance}

Mandatory codetermination might also have a significant impact on "bankruptcy governance,"169 complicating

166 Gesetz über die Mitbestimmung der Arbeitnehmer [MitbestG] [Codetermination Act], May 4, 1976, BGBL I at 1153, § 23, last amended by Gesetz [G], Apr. 24, 2015, BGBL I at 642, art. 7 (Ger.).

167 For the complete proposals, see supra note 7.

168 See Eric L. Johnson, Waste Not, Want Not: An Analysis of Stock Option Plans, Executive Compensation, and the Proper Standard of Waste, 26 J. Corp. L. 145, 169 (2000); John C. Coates IV, Measuring the Domain of Mediating Hierarchy: How Contestable Are U.S. Public Corporations?, 24 J. CoRP. L. 837, 860 (1999); William W. Bratton \& Joseph A. McCahery, The Equilibrium Content of Corporate Federalism, 41 WAKE FoREST L. REV. 619, 689 (2006).

169 On bankruptcy governance, see generally Kenneth M. Ayotte, Edith S. Hotchkiss \& Karin S. Thomburn, Governance in Financial Distress and Bankruptcy, in The OxFORD HANDBOOK OF CORPORATE GOVERnANCE 489 (Douglas Michael Wright et al. eds., 2013). 
decisionmaking processes especially in Chapter 11 restructurings in the United States.

The starting principle for both U.S. and German corporate bankruptcy laws is creditor governance.170 Key decisions, such as the approval of a restructuring plan, require the consent of a majority of the creditors. ${ }^{171}$ This protects the parties with money on the line. As the new residual claimants on the distressed corporation's income stream, creditors should have a decisive say on the use of the corporation's assets post-bankruptcy.

Codetermination on corporate boards complicates bankruptcy governance. On the one hand, one could argue that employee involvement in the strategic decision-making of a corporation is especially important in bankruptcy. After all, it is not only the creditors' money that is at stake but also the employees' jobs. Difficult decisions about the future of the distressed firm should be put on a broad foundation, if possible. On the other hand, bankruptcy requires swift decisionmaking and action. Firms lose value while subject to a bankruptcy process day-by-day, 172 and codetermination inevitably slows down decisionmaking. 173

Thus, under German bankruptcy law, the codetermination scheme that applies outside bankruptcy does not apply in court-supervised bankruptcy proceedings. Typically, even in going concern sales an insolvency administrator receives the powers to manage the distressed firm's assets that-outside bankruptcy_the management and the supervisory board

170 See Horst Eidenmüller, Comparative Corporate Insolvency Law, in THE OXFord HANDBOOK OF CORPORATE LAW AND GOVERNANCE 1003, 101820 (Jeffrey N. Gordon \& Wolf-Georg Ringe eds., 2018).

171 See id. at 1027.

172 On the costs of bankruptcy proceedings, see Michelle J. White, The Costs of Corporate Bankruptcy: A U.S.-European Comparison, in Corporate Bankruptcy: Economic And Legal Perspectives 467, 490-91 (Jagdeep S. Bhandari \& Lawrence A. Weiss eds., 1996).

173 For a discussion of the effects of codetermination on board functioning, see supra Section VI.A. 
would exercise.174 German bankruptcy law has Debtor-inPossession (DIP) proceedings similar to the United States. 175 However, these are rarely used. In the period from March 2012 to March 2017, less than 3.5\% of all corporate insolvency proceedings were DIP proceedings. 176 Hence, codetermination on corporate boards is practically irrelevant in German corporate restructurings, allowing the insolvency administrator to take swift decisions.

The adoption of either the Sanders or the Warren proposal would shift U.S. bankruptcy law and practice away from its current framework. 177 Chapter 11 corporate restructurings are almost always DIP proceedings. 178 Thus, in principle, the governance system that applies outside bankruptcy continues to apply in bankruptcy. 179 With respect to codetermination, this means that the debtor's deliberation on a restructuring plan would be fraught with difficult discussions between shareholder and employee representatives. For example, shareholder and employee representatives typically have very different views on the necessity, size and timing of layoffs, the sale or closure of certain business units, and more. These

174 See Insolvenzordnung [InsO] [Insolvency Statute], Oct. 5, 1994, BGBL I at 2866, §80, last amended by Gesetz [G], Dec. 20, 2011, BGBL I at 2854, art. 19 (Ger.).

175 See id. $\S$ 270-85.

176 See Floran Jacoby et Al., Evaluierung: Gesetz Zur weiteren ERLEICHTERUNG DER SANIERUNG VON UNTERNEHMEN (ESUG) VOM 7. Dezember 2011 [Evaluation: LAW to Further Facilitate the REORganization OF COMPANIES OF DECEMBER 7, 2011] 8 (2017), https://www.bmjv.de/SharedDocs/Downloads/DE/News/Artikel/101018_Ges amtbericht_Evaluierung_ESUG.pdf?_blob=publicationFile\&v=2 [https://perma.cc/WS9Z-DCZA].

177 Neither proposal purports to change U.S. bankruptcy law. However, the proposals would affect "bankruptcy governance" in Chapter 11 proceedings.

178 See A. Mechele Dickerson, A Behavioral Approach to Analyzing Corporate Failures, 38 WAKE FOREST L. REV. 1, 37 n.136 (2003) ("In most Chapter 11 cases, a Trustee is not appointed and the debtor continues to operate the firm as a debtor-in-possession[.]").

179 Of course, the debtor is now subject to fiduciary duties that it did not have outside of bankruptcy. See 11 U.S.C. § 1107(a) (2018). But the overall governance structure remains unchanged. 
differences inevitably will complicate and delay decision on a restructuring plan, creating additional transaction and opportunity costs. This would be a significant downside of the codetermination regime were it introduced in the United States.

Of course, bankruptcy practice in the United States could change. For example, more creditors might move to appoint a trustee under 11 U.S.C. $\S 1104(\mathrm{a})$, and courts might be more open to such motions. Similarly, the 11 U.S.C. $§ 1107$ (a) duties of a DIP as a trustee might discipline conflicts between different corporate stakeholder groups. But these developments would not undo the significant structural differences between the German and the U.S. bankruptcy system, and they would only reduce, not eliminate, the frictions created by introducing codetermination to the governance of large U.S corporations. 180

\section{The Market for Corporate Control}

Codetermination may also weaken the market for corporate control. The threat of hostile takeovers is an important mechanism to prevent managerial opportunism. ${ }^{181}$ However, mergers also come with the prospect of workforce reductions, 182 which means that employee representatives are

180 Another assessment could be warranted if Congress moved away from a DIP bankruptcy system. However, we believe that is an unlikely scenario.

181 See supra note 159; Lucian A. Bebchuk \& Kobi Kastiel, The Perils of Small-Minority Controllers, 107 GEO. L.J. 1453, 1465 \& n.32 (2019).

182 See Andrei Shleifer \& Robert W. Vishny, The Takeover Wave of the 1980s, 249 SCIENCE 745, 747 (1990) ("[L]ayoffs rise after hostile takeovers. Among the 62 targets of hostile takeovers between 1984 and 1986, the total post takeover layoffs were about 26,000 people, which amounts to about $2.5 \%$ of the labor force of an average target firm.”); Jiwook Jung, Shareholder Value and Workforce Downsizing: 1981-2006, 93 Soc. ForCES 1335, 1345 (2015) ("[M]any . . cases suggest that downsizing is likely to occur as part of post-M\&A restructuring[.]"); Jun-Koo Kang et al., PostTakeover Restructuring and the Sources of Gains in Foreign Takeovers: Evidence from U.S. Targets, 79 J. BUS. 2503, 2514 tbl.5 (2006) (reporting data on layoffs in takeovers). 
likely to oppose them.183 This is consistent with the experience in Germany, where commentators generally view codetermination as an obstacle to the market for corporate control. 184

Of course, such opposition can be efficiency-enhancing to the extent that a merger's externalities affecting the target firm's employees outweigh benefits to the firm's shareholders. However, we know of no empirical evidence showing that this is typically the case. 185 More importantly, assuming that employee representatives seek to maximize their chances of reelection, there is no reason to believe that they will take into account the benefits accruing to shareholders when deciding whether to oppose a merger. Rather, as long as the merger threatens to reduce employment, a self-interested employee representative is likely to vote against it even when the benefits to shareholders outweigh the costs to employees.

In principle, this conflict of interest exists in Germany and the United States. However, there are compelling reasons to think that opposition to takeovers is a lesser problem in Germany. The main reason is that, traditionally, there have been very few hostile takeovers in Germany. A 2017 study

183 Cf. Mark J. Roe, Some Differences in Corporate Structure in Germany, Japan, and the United States, 102 YALE L.J. 1927, 1970 (1993) (arguing that codetermination makes takeovers "more difficult" since employee representatives oppose takeovers "that would disrupt employment").

184 See, e.g., Nico RAABE, Die Mitbestimmung IM AufsichtsRat [CODETERMINATION IN SUPERVISORY BOARDS] 177 (2011) (comparing German codetermination to a poison pill).

185 In fact, economists tend to argue that the benefits that takeovers bestow on shareholders outweigh the costs imposed on employees. See, e.g., Shleifer \& Vishny, supra note 182, at 748 ("[T]ransfers from employees clearly do take place after hostile takeovers, but their magnitude is small relative to the wealth gains of the shareholders."). However, we do not embrace this argument either, since the underlying evidence seems less than compelling. For example, Shleifer and Vishny point out that posttakeover layoffs seem to impact disproportionately "high-level white-collar workers" and argue that "[i]t is hard to worry too much about these layoffs, since unemployment among educated white-collar workers barely exists in the United States." Id. at 747. At the very least, this reasoning is contingent on assumptions about U.S. unemployment levels. 
that examined all German takeovers between 1981 and 2010 in which the acquirer was a public company identified only five hostile takeovers in total.186 The same study showed that the overall level of takeover activity was quite low. Between 1981 and 2010, there were 338 acquisitions in total, and in 2010 , the most recent year included in the study, the authors found a total of eight mergers. 187

Of course, these numbers could be higher if it were not for codetermination. However, there are many other obstacles to an active takeover market in Germany. For example, even though share ownership is now more dispersed in Germany than it was even twenty years ago, many public corporations still have shareholders with ownership stakes exceeding twenty-five percent. 188 That makes hostile takeovers quite difficult.189 In other words, while Germany's codetermination regime may render hostile takeovers more challenging, it is not clear that the number of hostile takeovers would be much higher in its absence. Herein lies a major difference between Germany and the United States. The United States has a particularly vigorous market for corporate control and stands to lose much more from imposing codetermination. 190

186 Ferdinand Mager \& Martin Feyer-Fackler, Mergers and Acquisitions in Germany: 1981-2010, 34 GLOB. FIN. J. 32, 35 (2017). Note that this number excludes financial firms, $i d$. at 34 , and that the study includes transactions where the acquirer's ownership stake after the transaction was at least twenty-five percent. $I d$.

187 Id. at 35 tbl.1.

188 See Ringe, supra note 85, at 510 tbl.1 (giving the ownership structures of DAX30 corporations as of 2014).

189 A large shareholder's decision to hold onto his stake makes it more challenging for the hostile acquirer to buy up enough of the remaining shares to gain control of the corporation. Cf. Marco Ventoruzzo, Europe's Thirteenth Directive and U.S. Takeover Regulation: Regulatory Means and Political and Economic Ends, 41 TEX. INT'L L.J. 171, 179 (2006) (noting that shareholders with formal or de facto control "can entrench their positions to thwart possible hostile takeovers").

190 Codetermination could also reduce the amount of beneficial shareholder activism. If codetermined boards are larger, activist investors might find it more difficult to run a short slate campaign successfully as shareholders might fear further balkanization of the board. A proper analysis of this issue is beyond the scope of this Article. 
Between 1981 and 2010, the United States saw 60,244 mergers in which the acquirer and the target were public companies. 191

\section{E. Mandatory Corporate Law}

One of the less obvious costs of codetermination lies in the need to reduce the flexibility of corporate law to prevent regulatory arbitrage. Corporations may seek to find some way around the mandatory codetermination rules; therefore, lawmakers need to adopt additional mandatory rules to prevent circumvention of the codetermination regime. This problem exists in both Germany and the United States. However, the costs of adding mandatory law are likely to be much higher in the United States than they are in Germany.

\section{Preventing Circumvention}

Regulatory arbitrage can occur in one of several ways. Corporations can reincorporate offshore, they can convert into domestic entities such as partnerships so that codetermination rules do not apply, or they can amend their charters and bylaws in ways that minimize the impact of codetermination. We address these different approaches in turn.

\section{i. Reincorporation}

Firms seeking to avoid codetermination can incorporate or reincorporate in a foreign jurisdiction that does not impose any codetermination requirement. The German experience with this problem is telling. Based on the so-called "Freedom of Establishment" guaranteed by the Treaty on the Functioning of the European Union,192 German

191 We draw the figure from the Refinitiv SDC Platinum database. See SDC Platinum, REFINITIV (last visited Nov. 14, 2020), https://www.refinitiv.com/en/products/sdc-platinum-financial-securities [https://perma.cc/W4MC-PEMG] (describing the database).

192 See Consolidated Version of the Treaty on the Functioning of the European Union arts. 49, 54, Mar. 30, 2010, 2010 O.J. (C 83) 47. For a 
entrepreneurs are free to incorporate or reincorporate in another Member State, adopting a non-domestic corporate form. 193 Since 2004, corporations incorporated in one of the European Union (EU) Member States can transform into a European Societas Europaea (SE) - a European stock corporation. 194 In the first instance, the rules of the SE Regulation govern an SE.195 In addition, the laws on stock corporations of the jurisdictions in which the SE incorporates apply to the extent that the SE Regulation allows. 196 Unlike a German entity, an SE can have either a one-tier (administrative board) or two-tier (management board and supervisory board) board structure. 197

A separate European Directive governs issues of employee involvement-including employee board representation-in an SE.198 Upon an SE's formation, shareholder and employee representatives must negotiate the terms of employee involvement. 199 Crucially, if these negotiations fail, the most stringent participation regime of one of the entities involved in forming the SE governs. 200

After a slow start, the SE has become very popular amongst European firms. As of September 22, 2020, well over

discussion of the role of the Freedom of Establishment in allowing entrepreneurs from one Member State to incorporate in other Member States of the European Union, see Jens C. Dammann, Freedom of Choice in European Corporate Law, 29 YALE J. INT'L L. 477, 483-86 (2004).

193 See Jens Dammann, Homogeneity Effects in Corporate Law, 46 ARIZ. ST. L.J. 1103, 1143-44 (2014).

194 See Council Regulation 2157/2001, arts. 1-8, 2001 O.J. (L 294) 1, 36 (EC) (detailing several ways in which companies can change into a European company). A simple method allows a "public limited liability company" to transform into a European Company if it has had a subsidiary governed by the law of another Member State for at least two years. Id. art. 2 , $\$$. The term "public limited liability company" covers the various European Equivalents of the stock corporation. See id. annex 2 (listing the relevant entity types).

195 See id. art. 9(1)(a).

196 See id. art. 9(1)(b)-(c).

197 Id. art. 38(b).

198 See Council Directive 2001/86, 2001 O.J. (L 294) 22 (EC).

199 Id. art. 3(1).

200 See id. art. $7 \&$ annex. 
3,000 SEs existed in the EU.201 These comprise leading Eurozone companies such as Allianz and BASF but also many small and midsize entities. 202

As a corporate form, the SE is especially popular amongst German and Czech firms. As of March 13, 2018, over 2,000 SEs had registered in the Czech Republic and nearly 491 had in Germany. 203 Most of the Czech SEs are not operative, and the operative ones chose the SE form primarily to downsize the board.204 The key drivers for German SE formations are different. German firms reincorporate as SEs primarily to avoid board codetermination or mitigate its effects. 205 If a firm reincorporates as an SE before it has 500 employees, it can avoid board codetermination altogether. 206 If it reincorporates before it crosses the 2,000-employee threshold, it can freeze worker participation at one-third of the members of the supervisory board.207 And even if it already has more than 2,000 employees, it can downsize the supervisory board and internationalize the composition of the employee representatives on the board.208 The shareholders then have

201 See European Company (SE) Database - ECDB, WORKERPARTICIPATION.EU (last updated Nov. 29, 2020), http://ecdb.workerparticipation.eu/ [https://perma.cc/565J-NA7F].

202 ANDERS CARLSON, SE COMPANIES 15 (2018) http://www.workerparticipation.eu/European-Company-SE/Facts-Figures

[https://perma.cc/6RE4-WDG2] (click "SE-FactsFigures-2018-03-13

Bologna.pdf").

203 See id. at 3 fig.2943 European Companies (SEs), registered in 27 countries.

204 See Horst Eidenmüller \& Jan Lasák, The Czech Societas Europaea Puzzle, 12 J. CoRP. L. STUd. 237, 237-38 (2012).

205 Horst Eidenmüller, Andreas Engert \& Lars Hornuf, Incorporating Under European Law: The Societas Europaea as a Vehicle for Legal Arbitrage, 10 Eur. Bus. ORG. L. REv. 1, 32 (2009).

206 See Zweites Gesetz zur Vereinfachung der Wahl der Arbeitnehmervertreter in den Aufsichtsrat [One-Third Participation Act], May 18, 2004, BGBL I at 974, art. 1, § 1(1) (Ger.).

207 See Eidenmüller et al., supra note 205, at 8.

208 See Horst Eidenmüller, Lars Hornuf \& Markus Reps, Contracting Employee Involvement: An Analysis of Bargaining over Employee Involvement Rules for a Societas Europaea, 12 J. CORP. L. STUD. 201, 208 (2012). 
fewer and more diverse employee representatives with whom to negotiate, allowing the former to "divide and rule."209 For example, the shareholders representatives can play off the employee representatives of different countries against each other when deciding on the localization of investments or disinvestments.

In summary, the possibility of reincorporating as an SE has been used by many German firms to avoid or mitigate the effects of domestic codetermination laws. Crucially, there is nothing that the German lawmaker can do about this development. European law enjoys supremacy vis-à-vis Member States' laws. 210

In the United States, the danger that firms reincorporate in foreign jurisdictions exists as well, and the consequences may be worse. U.S. tax law already creates substantial incentives to incorporate offshore. If a corporation is incorporated in the United States, it is deemed to be a U.S. resident for tax purposes. 211 This means that, in principle, the corporation must pay taxes in the United States on its worldwide income.212 By contrast, if the corporation reincorporates in a foreign jurisdiction, the corporation will still have to pay taxes in the United States, but only on its U.S. income.213 Accordingly, corporations that conduct business in multiple countries may find it cheaper to incorporate in a low-tax foreign jurisdiction to minimize their

209 Id

210 See Jens C. Dammann, Introduction to European Union LaW 45 (2019).

211 See I.R.C. § 7701(a)(4) (2018).

212 See, e.g., Eric L. Talley, Corporate Inversions and the Unbundling of Regulatory Competition, 101 VA. L. REV. 1649, 1661 (2015). In 2017, the Tax Cuts and Jobs Act reduced the corporate tax rate to 21\%. Tax Cuts and Jobs Act of 2017, Pub. L. No. 115-97, sec. 13001, § 11(b), 131 Stat. 2054, 2096. This (temporarily) reduced the incentive to relocate abroad. President-elect Biden has proposed increasing the corporate tax to $28 \%$. Garrett Watson, Huaqun Li \& Taylor LaJoie, Tax Found., Details and Analysis of President-Elect Joe Biden's TaX Plan 1 (2020), https:/files.taxfoundation.org/20201109095935/Details-and-Analysis-ofPresident-Elect-Joe-Bidens-Tax-Plan.pdf [https://perma.cc/J3YQ-YBSZ].

213 Cf. id. at 1663-64 (working through an example). 
U.S. tax burden.214 This opportunity for tax arbitrage has given rise to so-called "corporate inversions," in which U.S. corporations merge into a foreign subsidiary, thereby shifting their place of incorporation abroad. 215

Until now, corporate law has provided U.S. corporations with an important reason not to follow this approach: incorporating abroad means accepting a foreign jurisdiction's corporate law, and many firms prefer U.S. corporate law, 216 which offers enormous flexibility. 217 However, if the United States were to enact a mandatory codetermination regime, this situation might well change. Such legislation could prompt U.S. firms to reincorporate abroad in greater numbers than before. Moreover, the consequences would be more severe than in Europe. Not only would such firms escape the reach of corporate law, but also they would pay less tax in the United States. Europe avoids the latter consequence due to a different approach to international taxation. 218 To prevent

214 See id. at $1650-51$.

215 Id. at 1650.

216 See id. at 1652 (arguing that U.S. multinational corporations prefer Delaware corporate law, which provides an important incentive not to reincorporate offshore).

217 See Lucian Arye Bebchuk, The Case for Increasing Shareholder Power, 118 HARV. L. REV. 833, 888 (2005) ("U.S. corporate law follows a clear and consistent 'enabling' approach-allowing incorporators to opt out of many state law provisions[.]"); Margaret M. Blair \& Lynn A. Stout, Specific Investment: Explaining Anomalies in Corporate Law, 31 J. CoRP. L. 719, 742 (2006) ("U.S. corporate law is comprised mostly of 'default rules.").

218 The bilateral tax treaties between EU Member States generally correspond to the Model Tax Convention on Income And on Capital (ORG. For Econ. Coop. \& Dev. 2017). See Jens Dammann, A New Approach to Corporate Choice of Law, 38 VAND. J. TransnaT'L. L. 51, 71 (2005). The OECD model provides that both a corporation's place of incorporation and its place of management are sufficient to establish tax residency. MODEL TAX Convention art. 7(1). However, if these two criteria diverge, the place of management determines a corporation's tax residency. Id. art. 4(3). As a result, if a corporation is headquartered in one Member State and moves its place of incorporation to another Member State, this move does not impact its tax status. See Dammann, supra, at 71-72. The European Commission maintains a list of the tax treaties between EU Member States. See Treaties for the Avoidance of Double Taxation Concluded by Member States, EuR. COMM'N (last visited Nov. 15, 2020), 
corporations from avoiding codetermination by reincorporating abroad, federal law likely would need to provide that U.S. rules on codetermination apply to all firms headquartered in the United States. Achieving compliance with such a fact-sensitive mandate would involve substantial transaction costs.

\section{ii. Conversion}

Corporations seeking to avoid codetermination also could convert into different entity types before reaching the quantitative thresholds that trigger the application of codetermination legislation or-in case of corporations already large enough to fall under the pertinent federal legislation-before the relevant legislation becomes effective.219 U.S. corporate law offers a variety of noncorporate entity types that provide limited liability, significant flexibility regarding governance arrangements, and the option of public trading. Entities providing these features include LLCs and limited partnerships. ${ }^{220}$ Currently,

https://ec.europa.eu/taxation_customs/individuals/personal-

taxation/treaties-avoidance-double-taxation-concluded-member-states_en [https://perma.cc/QEV5-2NTG].

219 Additionally, even once effective, the pertinent federal legislation may not require corporations to comply with the legislation immediately. For example, under Senator Warren's proposal, corporations that do not become large entities until after the Act takes effect have one year to obtain a federal charter under the Act. Accountable Capitalism Act, S. 3348, 115th Cong. $\S 4(\mathrm{a})(1)(\mathrm{B})$ (2018). If a corporation is a large entity at the time that the Act takes effect, the corporation would have two years to obtain a federal charter. Id. $\S 4(\mathrm{a})(1)(\mathrm{A})$.

220 LLCs offer limited liability to their owners. See DEL. Code AnN. tit. 6 , § 18-303(a) (2020). They also offer flexible governance arrangements. See Joseph A. McCahery, Comparative Perspectives on the Evolution of the Unincorporated Firm: An Introduction, 26 J. CoRP. L. 803, 803 (2001) ("LLC[s] ... bundl[e] together limited liability, a flexible governance structure, and preferential tax treatment."); Matthew T. Bodie, Employment As Fiduciary Relationship, 105 GEO. L.J. 819, 863 (2017) ("LLCs have a flexible governance structure[.]"). Limited liability partnerships also offer the advantage of flexible governance structure. See Larry E. Ribstein, The Uncorporation and Corporate Indeterminacy, 2009 U. ILL. L. REV. 131, 156 ("Limited partnerships ... offer 
the use of these forms as publicly-traded entities is the exception rather than the rule221: mainly, publicly-traded LLCs and partnerships can be found in the energy sector, where, under certain conditions, they offer the benefit of passthrough taxation.222 However, if federal law subjected corporations to codetermination while imposing no such requirement on other entity types, the popularity of noncorporate entities could skyrocket. Unlike Senator Sanders's proposal, Senator Warren's Accountable Capitalism Act partially addresses this problem because it applies to LLCs as well as to corporations. ${ }^{223}$ However, neither proposal applies to limited partnerships, let alone entity types such as trusts or limited liability partnerships.224 In order to prevent

contractual flexibility with few statutory constraints.”). Limited partnerships offer limited liability to limited partners. DEL. Code AnN. tit. $6, \S 17-303(\mathrm{a})$. By contrast, general partners are personally liable for the partnership's debts. Id. $\S \S 15-306(\mathrm{a}), 17-403(\mathrm{~b})$. However, by using a corporation or LLC as the general partner, limited liability partnerships can combine the benefit of limited liability with the partnership form.

221 See Suren Gomtsian, The Governance of Publicly Traded Limited Liability Companies, 40 DEL. J. CORP. L. 207, 222 (2015) (concluding that, as of 2013, only twenty LLCs traded publicly); Mohsen Manesh, Contractual Freedom Under Delaware Alternative Entity Law: Evidence from Publicly Traded LPs and LLCs, 37 J. CoRP. L. 555, 567 (2012) (searching 2011 SEC filings and finding twelve LLCs and seventy-three limited partnerships traded publicly). Note that publicly-traded limited partnerships are known as Master Limited Partnerships (MLPs). See John Goodgame, Master Limited Partnership Governance, 60 Bus. LAW. 471, 471 (2005) ("An MLP is a limited partnership, the limited partnership interests of which are publicly traded.”).

222 As a general rule, publicly-traded partnerships and LLCs are treated like C-corporations for tax purposes, meaning that they are subject to corporate income taxation. See I.R.C. § 7704(a) (2018). However, publiclytraded partnerships and LLCs avoid this consequence and retain passthrough taxation if they make at least $90 \%$ of their income from certain sources, including income from exploration and mining of natural resources such as oil or gas. Id. §7704(c)(2), (d)(1)(E).

223 Accountable Capitalism Act $\S \S 2(2)(\mathrm{A})(\mathrm{i}), 4(\mathrm{a})(1)$.

224 See id. $\S 2(2)(\mathrm{A})(\mathrm{i})$ (defining covered entities to include entities "organized under the laws of a State as a corporation, body corporate, body politic, joint stock company, or limited liability company"); Sanders, supra note 7 (proposing codetermination for "large corporations"). 
circumvention of mandatory codetermination, they would have to apply to such other entities as well.

\section{iii. Corporate Charters and Bylaws}

Even corporations that do not change their state of incorporation or their entity type may take measures to minimize the impact of codetermination. For example, under current law a corporation could shift responsibilities from the board of directors as a whole to particular board committees of which the employee representatives are not part.225 Furthermore, the corporation could adopt bylaws that adjust quorum and majority requirements for board decisions in such a way as to reduce the de facto role of workers' representatives. For example, if a board has traditionally adhered to a supermajority requirement for board decisions, 226 that corporation may shift back to a simple majority requirement. As long as the shareholder representatives account for a majority of board members-as they would under both Senator Warren's and Senator Sanders's proposals227—a simple-majority rule, which in Delaware corresponds to the legal default,228 will allow the shareholder representatives to make decisions against the will of the employee representatives.

To prevent firms from blunting the impact of codetermination by charter or bylaw provisions, a federal statute would have to impose minimum requirements regarding the decisionmaking process of corporate boards. German law has, in fact, taken this approach: it requires that employee representatives and shareholder representatives be

$225 C f$. Del. Code AnN. tit. 8, § 141(c) (2020) (allowing the board to establish committees by board resolution).

226 Under Delaware law, supermajority requirements for board decisions can be included in the certificate of incorporation or in the bylaws. See id. $§ 102(b)(4)$.

227 See Accountable Capitalism Act $\S 6(\mathrm{~b})(1)$; Sanders, supra note 7.

228 See Del. Code ANN. tit. 8, § 141(b) (allowing board decisions by simple majority vote of a quorum as long as neither bylaws nor charter require more). 
treated equally.229 Furthermore, the German Stock Corporation Act sharply limits the supervisory board's ability to delegate matters to committees: numerous essential responsibilities, such as the appointment or removal of officers, the calling of a shareholder meeting, and the approval of financial statements, cannot be assigned to committees at all. 230

\section{The Cost of Preventing Regulatory Arbitrage}

There is no question that federal law could address the various opportunities for circumvention outlined above.231 The costs of doing so, however, would likely be much greater in the United States than they are in Germany. The reason is that U.S. corporate law and German corporate law pursue very different regulatory strategies. U.S. corporate law is far more flexible than German corporate law,232 as it consists largely of default rules. ${ }^{233}$ By contrast, the provisions of the German Stock Corporation Act are mandatory unless provided otherwise. 234

A 2003 study by Katharina Pistor, Yoram Kleinan, Jan Kleinheisterkam, and Mark West is revealing in this context.235 The study compares the corporate law regimes of Chile, Colombia, Delaware, France, Germany, Israel, Japan,

229 See Bundesgerichtshof [BGH] [Federal Court of Justice] Feb. 25, 1982 , NeUE JuRISTISCHE WochENSCHRIFT [NJW] 1530, 1530-31 (Ger.).

230 See Aktiengesetz [AktG] [Stock Corporation Act], Sept. 6, 1965, BGBL I at 1089, § 107(3), last amended by Gesetz [G], July 17, 2017, BGBL I at 2446 , art. 9 (Ger.).

231 In order to be consistent, the U.S. would need to adopt such measures even if the goal of introducing codetermination is limited-as it may be under the Sanders and Warren proposals - to giving employees a voice in corporate decision-making as opposed to allowing them to actually take or block decisions as in a system of "parity codetermination."

232 See Dammann, supra note 106, at 448-56.

233 See supra note 217.

234 See Stock Corporation Act $§ 23(5)$.

235 Katharina Pistor et al., Innovation in Corporate Law, 31 J. CoMPAR. ECON. 676 (2003). 
Malaysia, and Spain.236 Of all these jurisdictions, the study concludes, Delaware has the most flexible law by far 237 - a fact praised by commentators. 238

The flexibility of U.S. corporate law implies, however, that the United States would face a fundamental transformation of its approach to corporate law if it were to adopt more mandatory rules. German corporate law heavily relies on mandatory law anyway, so preventing corporate charters and bylaws from circumventing codetermination creates little or no extra costs.

We are not arguing that either of these regulatory strategies is superior to the other-i.e., that corporate laws should be based primarily on defaults or on mandatory rules. Our point is simply that the latter system can accommodate mandatory rules to prevent legal arbitrage much more easily than the former. Even if the changes necessary to achieve this goal are fairly limited, they might well have significant structural spillover effects, impacting corporate law's basic architecture.

236 See id. at 689 tbl. 4

237 Id. at 689.

238 See Janet E. Kerr, Sustainability Meets Profitability: The Convenient Truth of How the Business Judgment Rule Protects a Board's Decision to Engage in Social Entrepreneurship, 29 CARDOZO L. REV. 623, 637 n.79 (2007) (noting the flexibility of Delaware corporate law as one reason why corporations choose Delaware). Empirical studies have shown that U.S. corporations prefer flexible corporate law. See, e.g., Brian Broughman, Jesse M. Fried \& Darian Ibrahim, Delaware Law As Lingua Franca: Theory and Evidence, 57 J.L. \& ECON. 865, 867, 869 (2014) (exploring "a sample of 1,850 start-up firms" and finding that states with "more flexible corporate law [were] somewhat more likely to retain in-state corporations"); Marcel Kahan, The Demand for Corporate Law: Statutory Flexibility, Judicial Quality, or Takeover Protection?, 22 J.L. Econ. \& ORG. 340, 341, 348 (2006) (exploring a sample of 3,807 observations and finding "substantial evidence that firms are more likely to incorporate in states with corporate law rules that offer firms flexibility to devise their governance arrangement in areas unrelated to takeovers"). 


\section{F. Risk-Taking}

Codetermination law also discourages certain types of risktaking. This incentive can be troublesome for any country, but it promises to be particularly daunting for the United States. That is because the United States economy relies particularly heavily on radical innovation and hence on risk-taking. Accordingly, it has more to lose from a corporate governance mechanism such as codetermination, which discourages risktaking. 239

\section{Codetermination and Risk-Taking}

It is a well-established principle in corporate finance that, given efficient capital markets, a corporation seeking to maximize shareholder wealth should choose the most profitable investment-defined as the investment with the highest net present value-regardless of the investmentspecific or firm-specific risk involved.240 The reason is that shareholders can easily eliminate investment- and firmspecific risks by diversifying their investments across firms. ${ }^{241}$ Hence, rational shareholders will be unwilling to accept lower profits in exchange for lower firm-specific risk. Why pay for a reduction in firm- or investment-specific risk by accepting lower profits if the shareholders themselves can eliminate the risks costlessly by diversification?

Employees, on the other hand, are in a different situation. They cannot protect themselves against firm-specific risks

239 Andreas Kokkinis and Konstantinos Sergakis voice a similar concern in the UK context. See Andreas Kokkinis \& Konstantinos Sergakis, A Flexible Model for Efficient Employee Participation in UK Companies, 20 J. CoRP. L. STUD. 453, 480 (2020) ("[I]ntroducing German-style codetermination would disrupt [the] ability [of UK firms] to innovate.").

240 See Richard A. Brealy, Stewart C. Myers \& Franklin Allen, Principles of Corporate Finance 645 (10th ed. 2011) ("Financial transactions undertaken solely to reduce risk do not add value in perfect markets.").

241 See id. at 646. 
easily. ${ }^{242}$ In the famous words of Branko Horvat, "[t]he owner can spread the risks by acquiring a diversified portfolio of shares, while the worker has just . . one job."243 If the firm goes bankrupt, employees who lose their jobs may not easily find adequate new employment.244 The reasons are myriad. For example, an employee may have invested heavily in firmspecific expertise that is without value to other firms. ${ }^{245}$ Some employees may find it difficult to move because of their family.246 And of course, potential employers may have insufficient information about job applicants and may, therefore, refrain from offering them positions and salaries commensurate with the value they can add. 247

Given that employees suffer disproportionately if a firm goes bankrupt yet stand to reap only a small fraction of the upside if the firm does particularly well,248 one cannot fault

242 See Jeffrey N. Gordon, The Shaping Force of Corporate Law in the New Economic Order, 31 U. RICH. L. REV. 1473, 1480 (1997); Marleen A. O'Connor, Restructuring the Corporation's Nexus of Contracts: Recognizing a Fiduciary Duty to Protect Displaced Workers, 69 N.C. L. REv. 1189, 1211 (1991).

243 Branko Horvat, The Political Economy of Socialism: A Marxist SOCIAL THEORY 447 (1982).

244 See Ronald J. Gilson \& Mark J. Roe, Lifetime Employment: Labor Peace and the Evolution of Japanese Corporate Governance, 99 CoLUM. L. REV. 508, 533 n.88 (1999) ("Information asymmetries between firms and employees render real-world labor markets imperfect and, hence, employees cannot depend on a perfectly fluid labor market.").

245 Cf. Margaret M. Blair, Ownership and Control: Rethinking Corporate Governance For the Twenty-First Century 230-31, 238-39 (1995) ("[Some] employees ... develop special skills that may be valuable only to [their current] employer.").

$246 C f$. Lisa B. Bingham, Employee Free Speech in the Workplace: Using the First Amendment as Public Policy for Wrongful Discharge Actions, 55 OHIo ST. L.J. 341, 356 \& n.59 (1994) (noting the challenges of relocation).

247 See Eliakim Katz \& Adrian Ziderman, Investment in General Training: The Role of Information and Labour Mobility, 100 ECON. J. 1147, $1148,1150-53$ (1990).

248 This outcome is no accident. Rather, "income-smoothing"-ensuring a regular income for employees over time-is a key advantage of employment relationships because employees need to put food on their family's table every day. See Hall, supra note 128, at 100 ("Under the reasonable assumptions that firms can borrow and lend and deal with 
employees for caring about the risks inherent in the firm's investments. 249 Specifically, employees will want their firm to refrain from making investments risky enough to jeopardize the survival of the firm. Codetermination ensures that employees' attitudes toward risk influence the decisionmaking process at the board level.250 Employee representatives who desire reelection hardly will want to jeopardize their prospects by agreeing to investments that workers oppose. Thus, it is reasonable to think that employee representatives generally will try to prevent corporate boards from "betting the farm." The empirical evidence is consistent with this narrative: German firms with paritycodetermination, as opposed to one-third codetermination, show lower idiosyncratic risk and more stable cash flows. 251

uncertainty more effectively than can individual workers, it makes good economic sense for firms to be financial intermediaries for their employees, spreading total compensation over the duration of the labor contract in a smooth, predictable way."). Of course, working for a profitable firm can have some benefits, possibly including higher wages or more promotions.

249 The fact that employees below the managerial level tend to be riskaverse is well known. See, e.g., Timothy P. Glynn, Beyond "Unlimiting" Shareholder Liability: Vicarious Tort Liability for Corporate Officers, 57 VAND. L. REV. 329, 410 (2004) ("Certainly, lower-level officers and employees-who have firm-specific investments of human capital, limited bargaining power, and limited wealth—are risk averse.”); O'Connor, supra note 242, at 1205 ("Employees are risk-averse. . . . [and] cannot diversify their risk because they usually have only one job."); $c f$. also Sharon Hannes, Reverse Monitoring: On the Hidden Role of Employee Stock-Based Compensation, 105 MicH. L. REV. 1421, 1432 (2007) (“[E]mployees tend to be risk-averse.").

250 See Franklin Allen et al., supra note 22, at 1317 ("[S]takeholder firms are more concerned with avoiding bankruptcy since this prevents their stakeholders from enjoying their benefits."); $c f$. also Michael A. Gurdon \& Anoop Rai, supra note 70, at 290 (pointing out that employees may be more interested in maintaining "stable employment" than in maximizing profits).

251 See, e.g., Chen Lin, Thomas Schmid \& Yuhai Xuan, Employee Representation and Financial Leverage, 127 J. Fin. Econ. 303, 321 (2018). 


\section{Risk-Taking and Radical Innovation as a U.S. Specialty}

Making firm-jeopardizing investments is not the only way to foster innovation. The economic literature distinguishes between different types of innovation; 252 one common distinction is between incremental and radical innovation. 253 Incremental innovation "build[s] on what is already there" 254 while radical innovation brings fundamental change and "create[s] new industries, products, or markets."255 Unsurprisingly, radical innovation is associated with greater risk-taking. 256

Institutional and legal structures influence the type of innovation at which each country excels. Some countries have liberal market economies (LMEs), in which "firms coordinate their activities primarily via hierarchies and competitive

252 There now exists a rich economic literature on different innovation styles. See, e.g. generally Torsten Ringberg, Markus Reihlen \& Pernille Rydén, The Technology-Mindset Interactions: Leading to Incremental, Radical or Revolutionary Innovations, 79 InDUs. MKTG. MGMT. 102 (2019) (discussing different innovation styles and analyzing the relationship between managerial mindset and innovation style); Christine S. Koberg, Dawn R. Detienne \& Kurt A. Heppard, An Empirical Test of Environmental, Organizational, and Process Factors Affecting Incremental and Radical Innovation, 14 J. High TECH. MGMT. Rsch. 21 (2003) (examining the role of environmental, organizational, and process factors on innovation).

253 See, e.g., Ringberg et al., supra note 252, at 103; Koberg et al., supra note 252 , at 23 .

254 See Koberg et al., supra note 252, at 23 (providing a survey of various definitions).

255 See id.

256 See Álvaro López Cabrales et al., Managing Functional Diversity, Risk Taking and Incentives for Teams To Achieve Radical Innovations, 38 Rsch. \& Dev. MGmT. 35, 35-37 (2008); Michael A. Witt \& Gregory Jackson, Varieties of Capitalism and Institutional Comparative Advantage: A Test and Reinterpretation, 47 J. INT'L BUS. STUD. 778, 784 (2016) (arguing that a reluctance to take risks may be compatible with incremental innovation but not with radical innovation). 
market arrangements." 257 Other countries have coordinated market economies (CMEs), in which "firms depend more heavily on non-market relationships to coordinate their endeavors with other actors and to construct their core competencies."258 Both theoretical considerations and the available empirical evidence suggest that, relatively, CMEs tend to be better at incremental innovation, whereas LMEs are better at radical innovation. 259

In this typology, the United States is an LME, 260 whereas Germany is either a CME261 or, in more recent literature, a combination of both types.262 Moreover, in line with the general findings on the relationship between economy and innovation type, the United States relies more on radical innovation, whereas Germany by and large focuses more on incremental innovation:

Germany specializes in technological developments that are just the reverse of those in the USA. . . Firms in Germany have been more active innovators in fields predominantly characterized by incremental innovation, including mechanical engineering, product handling, transport, consumer durables, and

257 Peter A. Hall \& David Soskice, An Introduction to VARIETIES OF Capitalism: The Institutional Foundations of Comparative Advantage 1, 8 (Peter A. Hall \& David Soskice eds., 2001).

258 Id.

259 See Witt \& Jackson, supra note 256, at 804 tbl.A2 (finding a significant negative correlation between radical innovation and market coordination); Hall \& Soskice, supra note 257, at 41 ("[T]he institutional framework of liberal market economies provide companies with better capacities for radical innovation, while those of coordinated market economies provide superior capacities for incremental innovation."). But see Mark Zachary Taylor, Empirical Evidence Against Varieties of Capitalism's Theory of Technological Innovation, 58 INT'L ORG. 601, 625 (2004) (arguing that empirical data do not support the predictions that the matching of varieties of capitalism with varieties of innovation).

260 Hall \& Soskice, supra note 257, at 19.

$261 \mathrm{Id}$.

262 See Witt \& Jackson, supra note 256, at 779 ("Germany, for instance, has evolved away from the pure-type coordinated market economy that it is commonly believed to represent."); see also id. at 803 tbl.A1 (giving a "coordination index" for twenty-two OECD countries). 
machine tools, while firms in the United States innovate disproportionately in fields where radical innovation is important, such as medical engineering, biotechnology, semiconductors, and telecommunications. 263

Other studies in economic and financial literature also are broadly consistent with the view that the U.S. economy specializes in risk-taking and radical innovation. Compared to other countries, the United States has a very active environment for startups, ${ }^{264}$ which ought to facilitate radical innovation. Furthermore, the United States has the most developed capital market in the world and is thus able to infuse new firms with massive amounts of capital quickly. 265

Moreover, there is substantial evidence that risk-taking is more prevalent in the United States than in other countries. For example, a 2008 study of risk-taking at the firm level in thirty-nine different countries found that, on average, risktaking is highest in the United States and Canada, and much lower in Germany. 266 In this context, it is also worth noting that firms in the United States, on average, face a higher probability of bankruptcy than firms in stakeholder countries such as Germany,267 a finding that is consistent with the assumption that U.S. companies take more risks.

263 Hall \& Soskice, supra note 257, at 43-44.

264 Stefano Breschi, Julie Lassébie \& Carlo Menon, A Portrait of Innovative Start-Ups Across Countries 19 fig.1 (Org. for Econ. Coop. \& Dev. Sci., Tech. \& Indus. Working Paper No. 02, 2018), https://www.oecdilibrary.org/docserver/f9ff02f4en.pdf?expires $=1606625789 \& i d=i d \&$ accname= $=$ guest $\&$ checksum $=\mathrm{A} 24193 \mathrm{E}$ DC4A2BE15D0C4173CBC33EB1C (showing the number of startups by country).

$265 C f$. Dammann, supra note 106, at 489 \& fig.2 (listing the world's top stock exchanges by domestic market capitalization).

266 See Kose John, Lubomir Litov \& Bernard Yeung, Corporate Governance and Risk-Taking, 63 J. FIN. 1679, 1681, 1697 tbl.II (2008) (examining the relationship between corporate governance and firm risktaking using a sample including firms from 39 countries).

267 See Franklin Allen et al., supra note 22, at 1319 tbl.I (using the Black-Scholes-Merton model to calculate the probability of a default for public corporations in four countries and finding that the risk of a default is 
Finally, it stands to reason that the sheer size of the U.S. economy puts the United States in a particularly good position to weather the potential downside of high-risk investments at the firm level. For small countries, the loss of even a single firm can be devastating. For example, before its decline, the Finnish mobile phone producer Nokia contributed about four percentage points to the country's total GDP.268 By contrast, the U.S. economy is large enough to withstand the collapse of even large firms. 269 The implosion of Enron, for example, had tragic consequences for its employees, many of whom also owned Enron stock, 270 but Enron's employees accounted for only a tiny fraction of the U.S. workforce. ${ }^{271}$ Admittedly,

almost twice as high for U.S. corporations (10.4\%) as for German firms $(6.6 \%))$.

268 Derek Scally, Finland Struggling to Find Way in Post-Nokia World, IRISH TIMES (April 17, 2015, 1:35 PM)

https:/www.irishtimes.com/business/technology/finland-struggling-to-findway-in-post-nokia-world-1.2178606 [https://perma.cc/V4SE-YF98].

269 Nevertheless, even in the United States, some firms, particularly banks, are considered too big to fail because their collapses would have severe repercussions. See John C. Coffee Jr., The Political Economy of DoddFrank: Why Financial Reform Tends To Be Frustrated and Systemic Risk Perpetuated, 97 CoRnell L. REv. 1019, 1056-57 (2012). For an excellent discussion of this topic and possible solutions, see generally Saule T. Omarova, The "Too Big to Fail” Problem, 103 Minn. L. Rev. 2495 (2019).

270 See Paul J. Lim, Don't Paint Nest Eggs in Company Colors, N.Y. Times, (Mar. 30, 2008),

https://www.nytimes.com/2008/03/30/business/30fund.html?auth=loginemail\&login=email [https://perma.cc/5AXM-DEWX]; Gretchen Morgenson, Lopsided 401(k)'s, All Too Common, N.Y. Times (Oct. 5, 2003), https://www.nytimes.com/2003/10/05/business/market-watch-lopsided-401$\mathrm{k}$-s-all-too-common.html [https://perma.cc/LV2W-66W9] (noting that the Enron 401(k) plan had invested sixty percent of its total assets in Enron's stock).

271 Prior to its bankruptcy, Enron had about 21,000 employees. Justin R. Kaufman, Comment, Halting the Enron Train Wreck: Using the Bankruptcy Code To Rescue Retirement Plans, 76 TEMP. L. REV. 595, 596 (2003). In the fourth quarter of that same year, total nonfarm employment in the United States was about 131,502,000. David S. Langdon, Terence M. McMenamin \& Thomas J. Krolik, U.S. Labor Market in 2001: Economy Enters a Recession, Monthly LAB. ReV., Feb. 2002, at 5 tbl.1. Thus, Enron accounted for about $0.016 \%$ of nonfarm employment in the United States. 
Germany is hardly at the other end of the spectrum. Currently, Germany is the fourth-largest economy in the world, 272 and its industrial giants occupy fields ranging from car manufacturing (BMW, Daimler, Volkswagen) to machinery (Siemens, KION), software (SAP), and pharmaceuticals (Bayer, Boehringer-Ingelheim, Merck). But this does not change the fact that the German economy is far smaller than that of the United States.

\section{CONCLUSION}

Critics have long scrutinized the idea that corporations ought to be managed primarily in the best interest of shareholders. The business judgment rule gives managers substantial leeway in protecting other stakeholders.273 However, the basic governance structure of U.S. corporations limits managerial autonomy. As long as shareholders retain the right to select corporate managers, corporations will be managed in the shareholders' interests. Moreover, there is little reason to believe that the commitment to shareholder wealth maximization has weakened. Over the last decades, the rise of institutional investors and legal reforms, such as say-on-pay and proxy-access, arguably have increased shareholders' power over corporations. 274

2724.2 World Development Indicators: Structure of Output, THE WORLD BANK (last visited Nov. 13, 2020), http://wdi.worldbank.org/table/4.2 [https://perma.cc/YS85-SB32] (displaying information on 2019 GDP by country).

273 See D. Gordon Smith, The Shareholder Primacy Norm, 23 J. CoRP. L. 277, 279-80 (1998) ("Outside the takeover context, ... application of the shareholder primacy norm to publicly traded corporations is muted by the business judgment rule." (footnote omitted)); Fisch, supra note 2, at 652 ("The business judgment rule provides a corporation's officers and directors with broad discretion to consider the interests of other stakeholders."); William W. Bratton, Confronting the Ethical Case Against the Ethical Case for Constituency Rights, 50 WASH. \& LEE L. REV. 1449, 1457 (1993) ("As a result [of the business judgment rule], management gets considerable latitude to derogate from the shareholder primacy norm as it makes decisions respecting investment, financing, and operations.").

274 For an excellent account of how shareholder power vis-à-vis CEOs has increased substantially, see generally Kahan \& Rock, supra note 164. 
Now, however, important voices are advocating for a fundamental shift away from the shareholder primacy model toward a more stakeholder-oriented approach to corporate governance. Two of the most influential figures on the political Left, Senator Elizabeth Warren of Massachusetts and Senator Bernie Sanders of Vermont, have put forth proposals that would allow the employees of large corporations to elect forty percent or even forty-five percent of all corporate directors. 275 These proposals are broadly similar to the German system of codetermination, in which employees of large companies can elect one-third or one-half of all board members, depending on the size of the company. 276

This Article illustrates that these proposals are highly unlikely to increase firm-level efficiency. We do not question that Germany has fared well with codetermination. On the contrary, Germany has enjoyed many decades of prosperity, technical innovation, and social peace. Codetermination has either furthered Germany's progress or, at least, has not stifled it. This achievement is all the more remarkable considering Germany weathered an unusual shock in the form of German unification. Any corporate law system that allows a major economy to flourish for many decades cannot be entirely bad.

But even if one assumes mandatory codetermination to be an efficient choice for German firms, there are compelling reasons to believe that it would be less desirable for firms in the United States. Given the different institutional, social, and economic environment, some core benefits of codetermination are unlikely to materialize in the United States. At the same time, some of the indisputable costs of codetermination likely would be much higher in the United States than they are in Germany.

As Kahan and Rock point out, "the balance of power between CEOs, boards, and shareholders has shifted notably in the last decade away from CEOs towards outside directors and shareholders." Id. at 1051; see also Rock, supra note 140, at 1910 ("[S]ince the early 1980s, the U.S. system has shifted from a manager-centric system to a shareholder-centric system.").

275 See supra notes 7-9 and accompanying text.

276 See supra Sections II.A-.B. 
Of course, it is conceivable that the pertinent institutional, economic, and social differences will diminish over time. For example, labor unions could once again play a dominant role in setting U.S. wages, which would allow codetermination to play an important part in avoiding conflicts between unions and employers. Perhaps U.S. securities law and capital markets will become less effective at allowing investors to monitor corporations, which would render codetermination more attractive as an alternative monitoring mechanism.

At this point, however, there is no reason to believe that these and other relevant changes will occur anytime soon. For the foreseeable future, therefore, proposals seeking to import mandatory codetermination will come with substantial economic costs. Consequently, the case for introducing codetermination in the United States would have to be made on non-economic grounds. 